\title{
Potential Application of Tetrapleura tetraptera and Hibiscus sabdariffa (Malvaceae) in Designing Highly Flavoured and Bioactive Pito with Functional Properties
}

\author{
Parise Adadi ${ }^{1, *(1)}$ and Osman N. Kanwugu ${ }^{2}$ (I) \\ 1 Department of Food Science, University of Otago, Dunedin 9054, New Zealand \\ 2 Institute of Chemical Engineering, Ural Federal University, Mira Street 28, Yekaterinburg 620002, Russia; \\ nabayire@gmail.com \\ * Correspondence: parise.adadi@postgrad.otago.ac.nz or pariseadadi@gmail.com
}

Received: 11 February 2020; Accepted: 30 March 2020; Published: 3 April 2020

\begin{abstract}
Sorghum beer (pito) is an indigenous alcoholic beverage peculiar to northern Ghana and parts of other West African countries. It is overwhelmed with calories, essential amino acids (such as lysine, etc.), B-group vitamins, and minerals. In recent years, there has been a growing demand for highly flavoured yet functional pito in Ghana; however, the local producers lack the prerequisite scientific expertise in designing such products. We propose the utilization of Tetrapleura tetraptera (TT) and Hibiscus sabdariffa (HS) as cheap and readily available materials in designing functional flavoured pito. The addition of TT and HS would not alter the fermentation profile but rather augment the starter with nutrients, thus improving the fermentation performance and shelf life of the final pito. In vitro and in vivo studies provide substantive evidence of antioxidant, nephro- and hepato-protective, renal/diuretic effect, anticholesterol, antidiabetic, and antihypertensive effects among others of the TT and HS, hence enriching the pito with health-promoting factors and consequently boosting the health of the consumer. Herein, we summarise the phytochemical, biological, pharmacological, and toxicological aspects of TT and HS as well as the technology involved in brewing the novel bioactive-flavoured pito. In addition, we also report the incidence of heavy metal in conventional pito.
\end{abstract}

Keywords: pito; Tetrapleura tetraptera; Hibiscus sabdariffa; functional beverage; bioactive; Vernonia amygdalina

\section{Introduction}

Sorghum beer, traditionally known as pito, is an alcoholic beverage native to northern Ghana and parts of other West African countries. It is largely brewed at households in Ghana, mainly from malted sorghum, water, 'yolga' (mostly crushed stem bark of Grewia mollis or Anogeissus leiocarpa or crushed okra stalk), and yeast (generally mixed culture obtained as a slurry from previous fermentation; referred to locally as 'dembila', 'dambeli', 'dabeli', or 'sabouli' in different parts of northern Ghana). It is worth knowing that other producers use millet as sole grain or mixed with the former grain during malting. In Ghana, pito is widely patronised within the Upper East and Upper West regions due to the thriving cultivation of sorghum [1]; nevertheless, there is a growing demand in the rest of the regions in Ghana. The art of brewing this sort of beverage is not consistent compared to western lager beer because it is brewed by indigenous folks who have little to no idea about the scientific processes involved. Therefore, the same batch of beer could have a different colour, flavour, and taste (from sweet to sour). Moreover, pito is a product of spontaneous fermentation, and evidently, different microorganisms have been isolated [2-5]. As reported in the literature, the hue varies from one producer to the other, ranging from golden yellow to dark brown [6]. This could be ascribed to the colour of the sorghum grains 
utilized during malting. Grains from different sorghum cultivars exhibit a wide myriad of colours, thus giving the final product its characteristic colour. Pito is enriched with carbohydrates, proteins, some vitamins, as well as lactic acids [6]; therefore, moderate consumption may have positive health benefits. Sefa-Dedeh et al. [7] documented four types of pito in Ghana, namely Nandom, Kokomba, Togo, and Dagarti. Basically, the same raw materials are utilized in brewing them. However, the uniqueness of each type could be associated to the methods of wort production, degree of malting and post-treatment of malts, temperatures under which the fermentation was carried out, and yeast strains utilized.

Tetrapleura tetraptera (TT) is a deciduous flowering plant from the family of the Fabaceae Mimosoideae and grows well in the rainforest zones of Africa [8]. The matured fruits are known as prekesse in Ghana and usually fall off the tree when matured. It is usually dried further before utilization (i.e., as herbal medicine, an ingredient for flavouring soup and stews, among others) [9]. A popular drink in Ghana called natu prekese drink is produced from TT (Figure 1). Nutritional and potential benefits of prekese have been highlighted by earlier researchers. It is documented to have flavonoids, phenols, cardiac glycosides, terpenoids, saponins, and phlorotannins, among others, thus exhibiting varying pharmacological effects. Moreover, it is utilized as a herbal medicine to cure numerous health conditions (i.e., jaundice, inflammation, convulsion, fever, epilepsy, and leprosy) [10-14]. Over 40 volatile compounds have been identified and quantified in prekese, which includes esters, aldehydes, alkenoates, higher alcohols, and carbonyl compounds [15,16], thus making it an ideal material for flavouring and fortifying pito.

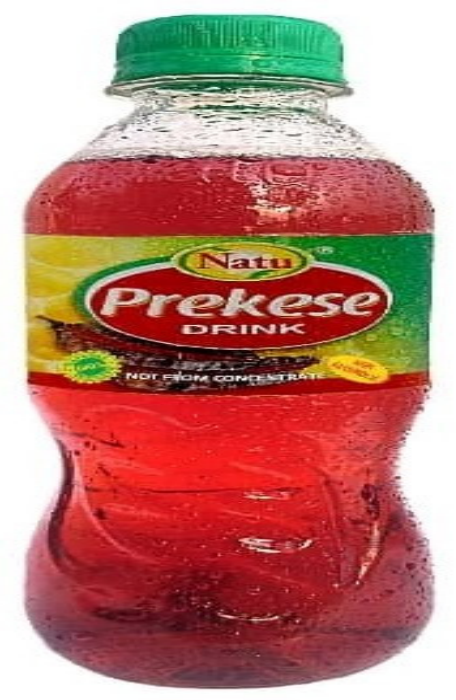

Figure 1. Local drink produced from Tetrapleura tetraptera [17].

Hibiscus sabdariffa (HS) is an annual, bristling, bushy, herbaceous shrub that can grow up to $8 \mathrm{ft}(2.4$ $\mathrm{m})$ tall, with smooth or nearly smooth, cylindrical, and typically red stems. It grows in well-drained soils; however, it can tolerate poor soils as well and hence thrives in soils across Ghana. The petioles are short, having alternate leaves, $7.5-12.5 \mathrm{~cm}$ long, and exhibiting a vine hue ranging from green to reddish [18,19]. A red calyx is developed from the stalking point (base) where the leave erects, consisting of five large sepals with a collar (epicalyx) and pointed bracts (or bracteoles) at the base, which enlarges, becomes fleshy, and crispy but juicy, enclosing light-brown seeds. When HS is matured, the capsule (housing) dries, turns brown, and splits open, displacing the seed [20,21]. The indigenes of northern Ghana utilise whole parts of HS. The leaves are used as vegetables when fresh; however, they can be dried and used during the dry season. The fresh or dried calyces are used in producing beverages popularly known as sobolobo (Figure 2) across Ghana. The stalks are usually dried, and the fibre extracted. The indigenes use fibres for roofing detached mud houses and gardening. The seeds are roasted and eaten as an appetizer. Many studies have also documented some potential uses of 
calyces in fermented drinks, wine, jam, jellied confectionaries, ice cream, chocolates, puddings, and cakes [18,22-27]. Earlier studies have utilized extracts of HS (must) in producing wine [25,28,29]. The calyces are reported to contain potent bioactive ingredients, such as organic acids (citric, malic acids, etc.), anthocyanins, polysaccharides, and flavonoids [19,30-33].

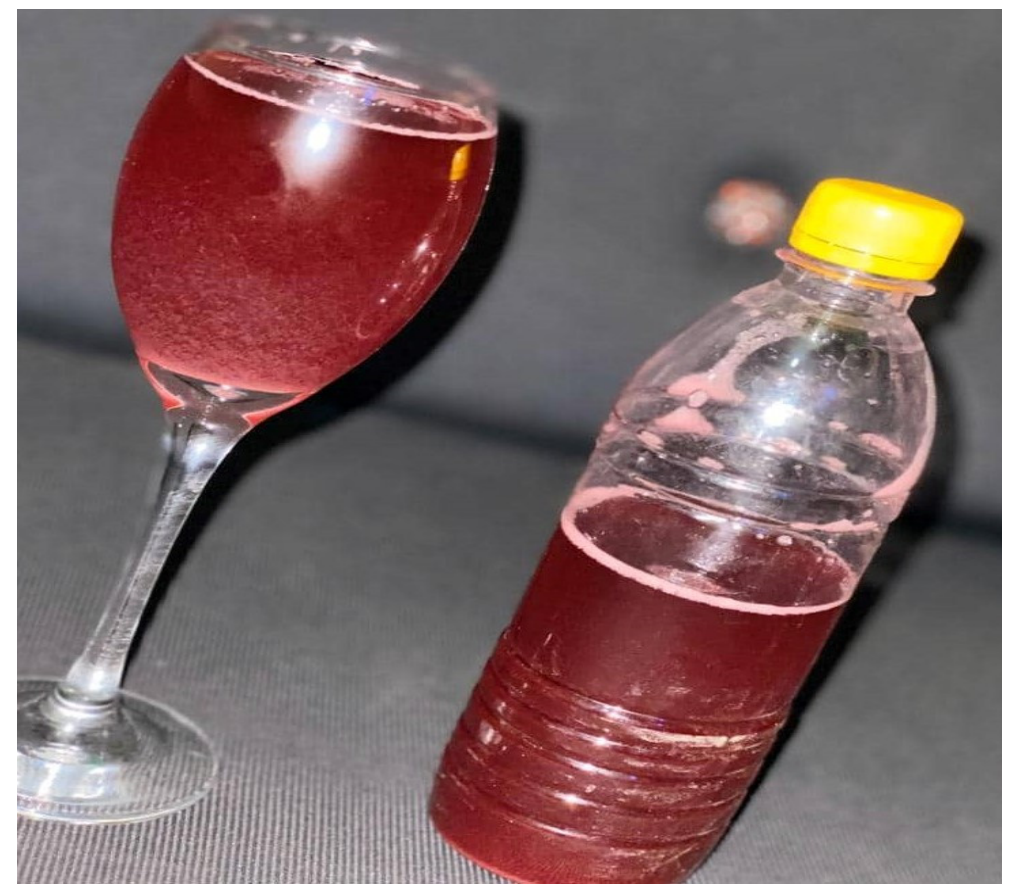

Figure 2. Locally produced sobolobo.

Recently, there is a growing demand for highly flavoured yet functional pito in Ghana; however, local producers lack the prerequisite technical (scientific) know-how in designing such products. Therefore, one potential possibility is to utilise TT (source of bioflavour and bioactive ingredients) and HS (bioactive ingredients) as inexpensive and readily accessible materials in designing functional flavoured pito. A recent report of the higher patronage of traditional gin 'akpeteshie' flavoured with prekese [9] further buttresses the feasibility of such a product. The development of products that confer beneficial effects on the health of the consumers is the theme of 21st century food research [34]. Other researchers have also utilised various fruits during brewing, with the aim of improving/increasing flavour and the bioactive/antioxidant potentials of beers [35-37]. However, a literature search on databases (Web of Science, PubMed, and Scopus) revealed that prekese and HS have not been utilized in designing beer of any sort, therefore, making the findings compounded in this manuscript a promising study. Moreover, the technological production of this novel pito is straightforward, hence local producers may adopt it to improve their profit.

Therefore, the present paper aims to report the potential application of local materials to design bioactive-flavoured pito with health-promoting benefits. Methods of designing the product with TT and HS are outlined. The phytochemical, biological, pharmacological, and toxicological aspects of TT and HS are elaborated as well as characterization of the final bioactive-flavoured pito.

\section{Proximate Composition of Pito}

The essence of consuming food and drinks is to provide necessary carbohydrates, proteins, lipids, dietary fibres, essential minerals, and vitamins required for the normal physiological functioning of the human system. Adazabra et al. [38] stated that the elemental composition of pito is of great importance for its nutritional value due to its involvement in various important physiological and metabolic processes of the body. According to [38,39], pito is overwhelmed with calories, essential 
amino acids (such as lysine, etc.), B-group vitamins (i.e., thiamine, folic acid, riboflavin, and nicotinic acid), as well as minerals (Table 1). A recent study [40] revealed that pito brewed using different raw materials (sorghum, millet, and corn) contained a vast myriad of nutrients. The authors reported that the proximate composition of the cereal-based alcoholic drinks (sorghum, millet and corn) were significantly different $(p<0.05)$ except for vitamin $\mathrm{B}_{2}$ (see Table 1$)$. Different brands of pito $(n=$ 8) were screened for 13 different elements (aluminium (Al), arsenic (As), barium (Ba), chlorine ( $\mathrm{Cl}$ ), cobalt $(\mathrm{Co})$, copper $(\mathrm{Cu})$, iron $(\mathrm{Fe})$, potassium $(\mathrm{K})$, magnesium $(\mathrm{Mg})$, manganese $(\mathrm{Mn})$, sodium $(\mathrm{Na})$, silicon (Si), and zinc $(\mathrm{Zn})$ ), and the results revealed that all brands were particularly rich in $\mathrm{K}>\mathrm{Cl}>$ $\mathrm{Mg}$. However, the rest were generally detected in varying concentrations. As reported by [41], the major elements detected in pito are present in bioavailable forms, thus they can easily be digested and assimilated by our body. Similarly, pito samples sourced from Bolgatanga, Tamale, Wa, and Accra, Ghana were analysed for their mineral composition. Essential minerals, such as $\mathrm{Na}, \mathrm{K}, \mathrm{Fe}, \mathrm{Zn}, \mathrm{Mn}$, $\mathrm{Cu}$, and $\mathrm{Ni}$ (nickel), were detected at higher concentrations, suggesting that pito is an excellent source of these minerals and could aid curb macronutrient deficiencies. The mean concentrations of $\mathrm{K}$ and $\mathrm{Na}$ in pito from Bolgatanga, Tamale, Wa, and Accra were 750.50 $\pm 90.25,942.67 \pm 176.97,694.75 \pm$ 117.50, and $790.00 \pm 9.19 \mathrm{mg} / \mathrm{L}$ and $21.75 \pm 12.20,28.33 \pm 9.71,60.25 \pm 4.19$, and $25.50 \pm 3.54 \mathrm{mg} / \mathrm{L}$, respectively [42]. The crude protein (\%), ash content (\%), and dry matter of pito were found to be 2.5 , 4.0, and 3.5, respectively. Additionally, [4] reported the concentrations (in ppm) of minerals ( $\mathrm{Mn}, \mathrm{Ca}$, and $\mathrm{Fe}$ ) in pito to be 110,1.11, and 5.30, respectively. From the evidence above, it can be concluded that pito is a good source of nutrients, especially the essential micronutrients; thus, moderate drinking might impact positively on the health of consumers. It is reported that pito is usually consumed by the poorest folks within society [43], who happen to be vulnerable to most micronutrient deficiencies; hence, drinking pito may help supplement their daily nutritional requirements.

Table 1. Nutritional composition of pito according to the literature.

\begin{tabular}{|c|c|c|c|c|}
\hline Nutrients & {$[40]$} & {$[44]^{\mathrm{c}}$} & {$[45]^{\mathrm{c}}$} & {$[46]^{\mathrm{c}}$} \\
\hline Crude protein & $\begin{array}{l}1.47 \pm 0.01 \mathrm{a} \% \\
1.95 \pm 0.01^{\mathrm{b} \%} \\
2.74 \pm 0.01^{\mathrm{c} \%}\end{array}$ & $3.70 \pm 0.02 \%$ & $8.7 \mathrm{~g}$ & $3.9 \mathrm{~g}$ \\
\hline Dry matter & $x$ & $x$ & $\times$ & $7.9 \mathrm{~g}$ \\
\hline Crude fat & $\begin{array}{l}0.52 \pm 0.01 \mathrm{a} \% \\
0.80 \pm 0.01 \mathrm{~b} \% \\
1.07 \pm 0.01 \mathrm{c} \%\end{array}$ & $0.31 \pm 0.01 \%$ & $0.3 \mathrm{~g}$ & $x$ \\
\hline Ash & $\begin{array}{l}0.92 \pm 0.01 \mathrm{a} \% \\
1.25 \pm 0.01 \mathrm{~b} \% \\
1.74 \pm 0.01 \mathrm{c} \%\end{array}$ & $1.50 \pm 0.01 \%$ & $4.1 \mathrm{~g}$ & $\times$ \\
\hline Available carbohydrate & $\times$ & $5.60 \pm 0.31 \mathrm{~g}$ & $x$ & 4.8 \\
\hline Crude fibre & $\times$ & $0.20 \pm 0.01 \%$ & $x$ & \\
\hline Moisture & $\begin{array}{l}91.05 \pm 0.00 \mathrm{a} \% \\
90.41 \pm 0.01 \mathrm{~b} \% \\
89.71 \pm 0.01 \mathrm{c} \% \\
\end{array}$ & $88.69 \pm 0.48$ & $x$ & $x$ \\
\hline Vitamin $B_{1}$ & $\begin{array}{l}0.0515 \pm 0.0005^{\mathrm{a}} \mathrm{IU} / \mathrm{mL} \\
0.0575 \pm 0.0005^{\mathrm{b}} \mathrm{IU} / \mathrm{mL} \\
0.0645 \pm 0.0005^{\mathrm{c}} \mathrm{IU} / \mathrm{mL}\end{array}$ & $x$ & $\times$ & $0.11 \mathrm{mg}$ \\
\hline Vitamin $B_{2}$ & $\begin{array}{l}0.0420 \pm 0.0010^{\mathrm{a}} \mathrm{mg} / 100 \mathrm{~mL} \\
0.0515 \pm 0.0005^{\mathrm{b}} \mathrm{mg} / 100 \mathrm{~mL} \\
0.0625 \pm 0.0005^{\mathrm{c}} \mathrm{mg} / 100 \mathrm{~mL}\end{array}$ & $x$ & $\times$ & 0.05 \\
\hline
\end{tabular}


Table 1. Cont.

\begin{tabular}{|c|c|c|c|c|}
\hline Nutrients & [40] & {$[44]^{\mathrm{c}}$} & {$[45]^{c}$} & {$[46]^{c}$} \\
\hline Vitamin $B_{6}$ & $\begin{array}{l}0.035 \pm 0.0005^{\mathrm{a}} \mathrm{mg} / 100 \mathrm{~mL} \\
0.046 \pm 0.0010^{\mathrm{b}} \mathrm{mg} / 100 \mathrm{~mL} \\
0.052 \pm 0.0010^{\mathrm{c}} \mathrm{mg} / 100 \mathrm{~mL}\end{array}$ & $x$ & $x$ & $x$ \\
\hline Vitamin C & $x$ & $\times$ & $x$ & 0.04 \\
\hline Calcium & $\begin{array}{c}24.625 \pm 0.005^{\mathrm{a}} \mathrm{mg} \\
29.80 \pm 0.010^{\mathrm{b}} \mathrm{mg} \\
31.57 \pm 0.010^{\mathrm{c}} \mathrm{mg}\end{array}$ & $x$ & $20.7 \mathrm{mg}$ & $2.2 \mathrm{mg}$ \\
\hline Iron & $\begin{array}{l}1.865 \pm 0.005^{\mathrm{a}} \mathrm{mg} \\
2.055 \pm 0.015^{\mathrm{b}} \mathrm{mg} \\
2.460 \pm 0.010^{\mathrm{c}} \mathrm{mg}\end{array}$ & $x$ & $x$ & $2.55 \mathrm{mg}$ \\
\hline Zinc & $\begin{array}{l}1.040 \pm 0.010^{\mathrm{a}} \mathrm{mg} \\
1.680 \pm 0.010^{\mathrm{b}} \mathrm{mg} \\
2.485 \pm 0.015^{\mathrm{c}} \mathrm{mg}\end{array}$ & $x$ & $x$ & $x$ \\
\hline Magnesium & $\begin{array}{l}48.675 \pm 0.015^{\mathrm{a}} \mathrm{mg} \\
61.965 \pm 0.015^{\mathrm{b}} \mathrm{mg} \\
68.350 \pm 0.010^{\mathrm{c}} \mathrm{mg} \\
\end{array}$ & $x$ & $x$ & $x$ \\
\hline Potassium & $\times$ & $\times$ & $1101 \mathrm{mg}$ & $84 \mathrm{mg}$ \\
\hline Sodium & $x$ & $x$ & $26.9 \mathrm{mg}$ & 1.1 \\
\hline Niacin & $x$ & $x$ & $8 \mu \mathrm{g}$ & 0.43 \\
\hline Riboflavine & $x$ & $x$ & $760 \mu \mathrm{g}$ & \\
\hline Thiamine & $\times$ & $x$ & $3441 \mu \mathrm{g}$ & \\
\hline Phosphorus & $x$ & $x$ & $x$ & 39 \\
\hline Pantothenic acid & $\times$ & $\times$ & $\times$ & 0.09 \\
\hline Energy value (kJ/g) & $x$ & $164.00 \pm 3.12$ & 394 & 164 \\
\hline
\end{tabular}

\section{Tetrapleura Tetraptera}

\subsection{Nutritional Profile}

The proximate composition of prekese is well elucidated, and [47] reported the ash (3.17-3.48), crude protein (5.13-8.65), sugar (3.29-39.63), and starch (7.56-29.10) content of prekese based on the percentage dry weight. The mineral content $(\mathrm{mg} / \mathrm{kg})$, including iron (Fe; 29.69-65.06), zinc ( $\mathrm{Zn}$; 5.35-25.16), copper (Cu; 4.00-12.54), magnesium (Mg; 392.35-2951.28), manganese (Mn; 16.23-178.91), sodium (Na; 119.48-2364.93), calcium (Ca; 1348.63-13839.86), potassium (K; 8631.09-14881.00), and boron (B; 1.14-6.23), were also quantified. In a similar study, [14] quantified, in percentage (\%), the protein (5.61-6.69), moisture (5.06-8.22), fats (11.19-24.71), carbohydrates (58.48-63.86), ash (2.65-4.02), and fibre (3.14-4.11) contents. In addition, various minerals $(\mathrm{mg} / 100 \mathrm{~g})$ were also detected: Mn (322.00-342.00), K (251.22-288.62), Ca (182.11-200.02), Mg (92.56-98.66), Na (19.95-26.80), P (36.22-43.11), Fe (16.11-18.22), Zn (10.75-16.24), and $\mathrm{Cu}(8.22-10.11)$ along with vitamin A (3.22-4.69), vitamin $\mathrm{E}(2.66-3.69)$, vitamin $\mathrm{C}(0.88-1.20)$, niacin $(0.11-0.12)$, thiamine $(0.01-0.04)$, and riboflavin (0.01-0.03).

The seeds contain chlorophyll a, chlorophyll b, $\beta$-carotene, and xanthophyll in the following concentrations $(\mu \mathrm{g} / 100 \mathrm{~mL}): 470.25 \pm 74.58,225.50 \pm 30.13,0.35 \pm 0.03$, and $180.90 \pm 16.22$, respectively [48]. With reference to the above data, it can be said that the nutritional composition of prekese varies, which could be associated to differences in the location where the samples were sourced coupled with the soil and weather under which they were cultivated. Essential and non-essential 
amino acids were also quantified in prekese. The results revealed that prekese contains a total of 17 amino acids [49]. The predominant essential oil and fatty acids in prekese according to [16] are acetic acid (34.59\%), 2-hydroxy-3-butanone (18.25\%), butanoic acid (8.35\%), 2-methyl butanoic acid (7.58\%), 2-methyl butanol (7.45\%), butanol (4.30\%), 2-methyl butenoic acid (3.65\%), and nerol (3.25\%). The nutritional profiles stated above show that prekese could be utilized in intervention studies to curb the malnutrition menace plaguing the African continent.

\subsection{Phytochemical Composition}

Phytochemicals (phytonutrients) could be described as bioactive compounds found in plants with distinct activity toward the biochemistry and metabolism of consumers. Although, some phytochemicals are antinutritive. Originally, these vital compounds are synthesised by plants to help them thrive, thus killing competitors and pathogens. According to [50], phytochemicals are natural substances and are synthesised by plants neither via energy metabolism nor in anabolic or catabolic metabolism but only in specific cell types. In a quantitative analysis, [51] indicated (\%) that prekese had saponin $(5.670 \pm 0.294)$, tannin $(3.194 \pm 0.323)$, flavonoid $(0.073 \pm 0.002)$, alkaloids $(0.633 \pm 0.057)$, phenol $(0.373 \pm 0.013)$, and glycosides $(0.0072 \pm 0.0002)$. Similarly, [13] reported that the seeds of prekese contained phenols $(0.34 \pm 0.10)$, flavonoids $(0.91 \pm 0.12)$, alkaloids $(0.52 \pm 0.08)$, tannins $(0.23 \pm$ $0.02)$, and saponins $(0.51 \pm 0.01)$. The phytochemical contents of prekese were reported to be high in the pulp and woody shell compared to the seeds. Table 2 shows a summary of the phytochemicals in prekese [47]. In addition, Irondi et al. [52] reported the concentration of various phenolics in the composition (Table 3) of prekese.

Table 2. Phytochemical composition (mg/100 g) of dry fruit of prekese [47].

\begin{tabular}{llllll}
\hline Fruit Part & Total Polyphenols & Flavonoids & Saponins & Tannin & Phytate \\
\hline Seeds & $38.05 \pm 0.21^{\mathrm{C}}$ & $10.30 \pm 0.42^{\mathrm{C}}$ & $60.80 \pm 11.88^{\mathrm{C}}$ & $675.50 \pm 152.03^{\mathrm{B}}$ & $3545.00^{\mathrm{C}} \pm 77.78^{\mathrm{B}}$ \\
\hline Pulp & $1866.88 \pm 1.02^{\mathrm{B}}$ & $410.75 \pm 1.06^{\mathrm{A}}$ & $953.40 \pm 9.33^{\mathrm{A}}$ & $1097.50 \pm 26.16^{\mathrm{A}}$ & $5170.00 \pm 42.43^{\mathrm{A}}$ \\
\hline Woody shell & $2907.15 \pm 2.19^{\mathrm{A}}$ & $354.60 \pm 0.85^{\mathrm{B}}$ & $641.50 \pm 18.81^{\mathrm{B}}$ & $135.50 \pm 20.51^{\mathrm{C}}$ & $1^{1021.00 \pm 15.56^{\mathrm{C}}}$ \\
\hline Mean & 1604.03 & 258.55 & 551.90 & 636.17 & 3245.33 \\
\hline
\end{tabular}

Results presented as mean $(n=3) \pm$ standard deviation. Different capital letters (A to C) denote significant differences $(p<0.05)$ in the same column.

Table 3. Phenolics constituent of prekese fruits.

\begin{tabular}{cc}
\hline Phenolics & Concentration $(\mathrm{mg} / \mathrm{g})$ \\
\hline Gallic acid $^{1}$ & $2.95 \pm 0.01$ \\
\hline Catechin $^{1}$ & $0.43 \pm 0.03$ \\
\hline Chlorogenic acid $^{1}$ & $0.21 \pm 0.01$ \\
\hline Caffeic acid ${ }^{1}$ & $3.72 \pm 0.02$ \\
\hline Ellagic acid $^{1}$ & $3.69 \pm 0.04$ \\
\hline Epicatechin $^{1}$ & $1.38 \pm 0.01$ \\
\hline Rutin $^{1}$ & $1.74 \pm 0.01$ \\
\hline Quercitin $^{1}$ & $3.65 \pm 0.03$ \\
\hline Luteolin $^{1}$ & $0.45 \pm 0.02$ \\
\hline Apigenin $^{1}$ & $3.73 \pm 0.01$ \\
\hline Total phenol $^{2}$ & $27.48 \pm 0.16^{\alpha} 42.18 \pm 0.16^{\beta}$ \\
\hline Tannin $^{2}$ & $32.54 \pm 0.22^{\alpha} 46.99 \pm 0.17^{\beta}$ \\
\hline Total flavonoid $^{2}$ & $0.18 \pm 0.01{ }^{\alpha}$ \\
\hline
\end{tabular}

${ }^{1}[52] ;{ }^{2}$ [53]; $\alpha$-the mature green fruit; $\beta$-ripe brown fruit; Results are expressed as mean \pm standard deviations (SD) of triplicate determinations. 
Tannins are generally regarded as anti-nutrients because they interact with proteins and form insoluble complexes, thereby reducing their bioavailability. Their potential health benefits cannot be overlooked as it is widely accepted and known that tannins confer anti-tumour as well as biocidal activities and are utilized in ulcer management, wound healing, and the control of bleeding and burns [54-58]. They are also implicated in the astringent and poor taste of food and drink. Nonetheless, they may be drastically reduced due to thermal treatments (i.e., mashing, wort boiling) in the final pito. According to [59], the concentration of tannins in thermally treated corn kernel (8.55\%) was lower than the control (11.69\%).

Rausch et al. [60] highlighted that saponins exhibit antioxidant, anticancer, anti-inflammatory, hyperglycaemic, and antifungal potentials, thus positively contributing to the healthy life of consumers. It has also been documented that saponins may have the potential to combine with cholesterol, impart a bitter taste, and cause haemolytic activity in water-based solutions [61]. However, in the case of pito, this phenomenon may be rare since pito has a negligible amount of cholesterol.

Akin-Idowu et al. [47] detected phytate in prekese, which ranged from 135.5 to $1097.50 \mathrm{mg} / 100 \mathrm{~g}$. Phytate is known to inhibit the bioavailability of essential minerals. However, cooking/boiling could significantly reduce their concentration to levels insufficient to exhibit antinutritional potential.

There is a positive correlation between the total phenol and flavonoid contents and their antioxidant activities in prekese [62,63]. Plant phenols have gained increasing attention due to their potent action on oxidative stress-associated diseases, such as cancer, etc. Hydroxylated phenolic substances (flavonoids) may have potential in the management of patients suffering from coronary heart disease. Its biocidal activities against clinical viruses are well elucidated [64]. It is also effective against a wide array of inflammatory responses via many routes and the blockage of molecules like cyclooxygenase (COX), nitric oxide synthases (iNOS), cytokines, nuclear factor- $\mathrm{kB}$, and matrix [65].

\subsection{Biological Activities}

\subsubsection{Cytotoxic and Anti-Proliferative Activities}

An in vivo study revealed that the extract of prekese is toxic to Ehrlich-Lettre ascites carcinoma (EAC cells), with a positive correlation between the extract concentration and nonviable cells. The authors ascribed the mechanism underlying the cytotoxic activity to direct cytolytic effects, including tumour cell lysis. It was also observed that as tumour cells increase, so does the ascitic fluid, because ascitic fluid is the source of nutrition for tumour cells. An amount of $80 \mathrm{mg} / \mathrm{kg}$ prekese treatment had increased the rate of the life span of EAC-bearing mice by $22 \%$ by reducing the number of viable EAC cells $[66,67]$.

\subsubsection{Hepatoprotective Activities}

Okolie et al. [62] revealed that the treatment of laboratory mice with extracts of T. tetraptera and vitamin $\mathrm{E}$ significantly reduced the levels of liver function biomarkers, including alanine aminotransferase (ALT), aspartate aminotransferase (AST), alkaline phosphatase (ALP), and bilirubin, as well as the antioxidant parameter (MDA) in carbon tetrachloride $\left(\mathrm{CCl}_{4}\right)$-induced liver injury. In a similar study, the levels of AST and ALT activity were significantly $(p<0.05)$ reduced when alloxan-diabetic rats were treated with extracts of prekese as compared to the untreated groups [68].

\subsubsection{Anti-Inflammatory Effects}

Ojewole and Adewunmi [10] investigated the anti-inflammatory activity of aqueous extracts of prekese by using fresh egg albumin to induce pedal oedema in rats. Diclofenac (DIC, $100 \mathrm{mg} / \mathrm{kg}$ p.o.) was used as the reference anti-inflammatory agent. The results showed rats treated with prekese (50-800 $\mathrm{mg} / \mathrm{kg}$ p.o.) produced dose-related significant reductions $(p<0.05)$ of the fresh egg albumin-induced acute inflammation. However, the effects of the aqueous extract were found to be less than that of the reference drug (diclofenac). Additionally, orally administering prekese extracts at a dose of 100, 200, 
and $400 \mathrm{mg} / \mathrm{kg}$ resulted in a reduction of knee swelling by $1.54 \pm 0.27,0.67 \pm 0.14$, and $0.35 \pm 0.13 \mathrm{~mm}$ (corresponding to inhibition by $46.0 \%, 76.5 \%$, and $87.7 \%$ ), respectively, when compared to the arthritic control (2.85 \pm 0.09$)$ [69].

\subsubsection{Antidiabetic Activity}

In an in vivo study using a streptozotocin (STZ)-induced diabetes animal model and chlorpropamide (250 mg/kg p.o.) as the reference drug, [10] showed that prekese extract (TTE, $50-800 \mathrm{mg} / \mathrm{kg}$ p.o.) significantly reduced $(p<0.05)$ blood glucose concentrations of both fasted normal and fasted diabetic rats. It is believed that the mechanistic action exerted by the extract may be similar to that of the reference drug, chlorpropamide. Similarly, in a study with alloxan-induced diabetic male albino rats, it was observed that the activities of liver enzymes (AST and ALT), as well as bilirubin, were significantly increased in the control group compared to groups treated with either methanolic extracts or a standard antidiabetic drug (glibenclamide). At the experimental dose of $1 \mathrm{mg} / \mathrm{kg}$, prekese leave extract was effective in managing some biomarkers (total and direct bilirubin) compared to glibenclamide. Notably, the extract exhibited a significant percentage change in the fasting blood sugar of normal (non-diabetic) rats compared to diabetic rats [68]. Komlaga [70] also reported the positives effect of ethanolic extract of prekese in lowering blood glucose compared to glibenclamide. The hypoglycaemic potential of prekese is well documented [71].

\subsubsection{Antioxidant Activity (AOA)}

1,1-diphenyl-2-picrylhydrazyl (DPPH) radical scavenging and ferric-reducing antioxidant property (FRAP) assays were employed in screening the antioxidant activity (AOA) of fresh fruits and the stem bark of prekese extracts. The results revealed the DPPH radical inhibition (\%) ability of the stem bark and fruit ranged from $28.74-85.26 \%$ and $10.56 \%$ to $66.01 \%$, respectively. With respect to the FRAP, the reductive ability ranged from 0.393 to $1.641 \mathrm{mg}$ ascorbic acid equivalent/mL and 0.342 to $1.325 \mathrm{mg}$ ascorbic acid equivalent/mL for the stem bark and fruit extract, respectively. It was concluded that the stem bark performed better as an antioxidant agent than the fruit [72]. In a collaborative study, [73] used various assays, namely DPPH, FRAP, 2, 2' - azino- bis (3-ethylbenzothiazoline-6-sulfonic acid) (ABTS), hydroxyl radical, nitric oxide radical, metal chelating, and total antioxidant capacity (TAC), in evaluating the AOA of ethanolic and aqueous extracts of prekese. Both extracts exhibited free radical scavenging and AOA; nevertheless, the aqueous extract has comparatively more potent in vitro free radical scavenging activity and $\mathrm{AOA}$ than ethanolic extract. It was also revealed that the antioxidant potency was positively correlated with the total phenolic content. Furthermore, [74] stated that all extracts (CEH: T. tetraptera hydroethanolic bark extract; CFH: T. tetraptera hydroethanolic fruit extract; CEE: T. tetraptera ethanolic bark extract; CFE: T. tetraptera ethanolic fruit extract) assessed exhibited various and diversified phenolics with free radical scavenging activities, antioxidant properties, and a high protective potential against oxidative-mediated ion toxicity. This was confirmed when the treated subjects showed an increase in the enzyme activities of superoxide dismutase (SOD), catalase (CAT), and glutathione peroxidase compared to the positive control. Numerous other researchers have also assayed the AOA of various extracts of prekese [53,69,75-78].

\subsubsection{Biocidal Activities}

Gberikon et al. [79] reported that the sensitivity pattern of test organisms (Streptococcus mutans and Streptococcus salivarius) to fruit extracts (aqueous and ethanol) of prekese was higher than the stem bark extract. The findings also revealed that ethanol extract produced clear zones of inhibition on the tested organisms than the aqueous extract. In addition, it was observed that for ethanolic extracts, while the stem bark extract at a concentration of $100 \mathrm{mg} / \mathrm{mL}$ inhibited the growth of Streptococcus mutans, a higher concentration $(400 \mathrm{mg} / \mathrm{mL})$ of the fruit extract was needed to inhibit the growth of Streptococcus mutans. It could therefore be presumed that the ethanol in pito would result in higher extraction of these compounds responsible for this biocidal activity in pito, which might ultimately lessen microbial 
contamination in the final product. Achi [80] correspondingly documented a high sensitivity after screening the extract of prekese against important foodborne bacteria. Among the test organisms, Escherichia coli (ATCC11775), Pseudomonas aerugionsa (ATCC10145), and S. aureus (ATCC12600) showed higher sensitivity than Bacillus. subtilis (ATCC6051). According to the author, the minimum inhibitory concentration (MIC) of the extract was $250 \mu \mathrm{g} / \mathrm{mL}$ against E. coli, P. aeruginosa, and Staphylococcus aureus. However, for B. substilis, the MIC of the plant extract $(500 \mu \mathrm{g} / \mathrm{mL})$ was found to be higher than those of the control (sorbic acid $(250 \mu \mathrm{g} / \mathrm{mL}$ or benzoic) acid. The fungicidal activity of prekese seed extract against important fungi, such as Aspergillus niger, Penicillium notatum, and Candida albican, has also been reported [13].

\subsection{Toxicological Aspect}

Noamesi et al. [81] reported that acute cytotoxic concentrations of prekese $(438 \mu \mathrm{g} / \mathrm{mL})$ extracts killed $50 \%\left(\mathrm{LC}_{50}\right)$ of brine shrimp within $24 \mathrm{~h}$. The extract was still effective when applied in conjunction with other extracts Guibourtia ehie and Taverniera abyssinica; however, G. ehie alone did not kill the shrimps even at $2 \mathrm{mg} / \mathrm{mL}$, indicating that prekese contributed significantly to the potent bioactivity. When two species of fish, Tilapia nilotica and T. galilaea, were treated with prekese, both fishes died after $24 \mathrm{~h}$; however, the former showed an $\mathrm{LC}_{50}$ at 0.35 whereas the latter was $0.44 \mathrm{ppm}$, indicating differences in the susceptibility to the extract among the fish species [82]. Ethanol extract of prekese was also reported to elicit selective toxicity at various concentration. The extracts did not induce pathological lesion in the liver; however, they resulted in an elevation of AST and other metabolic biomarkers. The authors recommended a minimum oral intake of $50 \mathrm{mg} / \mathrm{kg}$ bodyweight [83]. In addition, aqueous extract of TT (8000-12,000 mg/kg) manifested signs and symptoms of toxicity ranging from weakness, reduced respiration, and locomotor activity to death. However, the authors concluded that the extract was practically non-toxic, hence it could be classified as non-toxic since the $\mathrm{LD}_{50}$ value was found to be $10.0 \mathrm{~g} / \mathrm{kg}$ [84].

\section{Hibiscus Sabdariffa (Malvaceae)}

\subsection{Nutritional Profile}

Various laboratories across the globe have contributed to the determination of proteins, fatty acid profile, essential oil composition, carbohydrates, crude fibre, total phenolic content, flavonoids, and minerals of HS in order to understand and utilise HS or its components in intervention studies. Juhari and Petersen [85] screened the seeds of HS and found them to contains moisture $(8.4 \pm 0.10 \%)$, protein $(21.3 \pm 0.9 \%)$, total dietary fibre $(47.3 \pm 1.4 \%)$, carbohydrate $(0.3 \pm 0.1 \%)$, lipids $(16.2 \pm 0.5 \%)$, and ash $(6.5 \pm 0.0 \%)$. Salah and Hayat [86] investigated HS seed flour and defatted flour for their proximate composition, nitrogen solubility, and functional properties of protein isolates. They reported (in\%) the moisture content, crude protein, crude fibre, ash, fat, and nitrogen-free extract for the former to be 4.95 $\pm 0.6,32.46 \pm 3.4,13.90 \pm 1.6,9.40 \pm 1.2,22.43 \pm 2.1$, and $16.86 \pm 1.7$ whereas these values were $7.05 \pm$ $0.8,46.46 \pm 4.3,9.65 \pm 1.3,12.45 \pm 1.4,4.34 \pm 0.6$, and $20.05 \pm 2.2$ for the defatted flour. The major fatty acids in HS seed are palmitic (9.2\%), oleic acid (33.5\%), and linoleic acid (44.2\%) [26]. Various classes of vitamins $(\mathrm{mg} / 100 \mathrm{~g})$ were also reported in HS: Folate $(6.26 \pm 0.03), \beta$-carotene $(8.96 \pm 0.01)$, vitamin $B_{2}$ $(0.27 \pm 0.03)$, vitamin $B_{3}(0.05 \pm 0.00)$, vitamin $B_{6}(0.80 \pm 0.01)$, vitamin $C(13.07 \pm 0.01)$, and vitamin $E$ $(0.07 \pm 0.01)$ [87].

Adanlawo and Ajibade [88] evaluated the red and green variety of HS, with each divided into two treatment groups. One group was soaked in wood ash overnight while the other was not. The red calyces of $\mathrm{HS}$ with and without soaking in wood were labelled $\mathrm{R}_{2}$ and $\mathrm{R}_{1}$, respectively, whereas the green calyces of $H S$ with and without soaking in wood were labelled $G_{2}$ and $G_{1}$, respectively. The minerals $(\mathrm{g} / 100 \mathrm{~g})$ reported for the red variety included: $\mathrm{Na}\left(\mathrm{R}_{1}: 96.66, \mathrm{R}_{2}: 87.43\right), \mathrm{K}\left(\mathrm{R}_{1}: 49.35\right.$, $\mathrm{R}_{2}$ : 118.30), $\mathrm{Ca}\left(\mathrm{R}_{1}: 12.65, \mathrm{R}_{2}: 16.12\right), \mathrm{Mg}\left(\mathrm{R}_{1}: 38.65, \mathrm{R}_{2}: 47.54\right), \mathrm{Fe}\left(\mathrm{R}_{1}: 3.22, \mathrm{R}_{2}: 2.41\right), \mathrm{Zn}\left(\mathrm{R}_{1}: 12.22\right.$, $\left.R_{2}: 16.61\right), M n\left(R_{1}: 2.39, R_{2}: 2.86\right), N i\left(R_{1}: 1.78, R_{2}: 2.09\right)$, and $P\left(R_{1}: 36.30, R_{2}: N D\right)$. On the other 
hand, the green variety contained $\mathrm{Na}\left(\mathrm{G}_{1}: 48.19, \mathrm{G}_{2}: 32.70\right), \mathrm{K}\left(\mathrm{G}_{1}: 49.59, \mathrm{G}_{2}: 77.78\right), \mathrm{Ca}\left(\mathrm{G}_{1}: 21.58\right.$, $\left.\mathrm{G}_{2}: 49.54\right), \mathrm{Mg}\left(\mathrm{G}_{1}: 47.54, \mathrm{G}_{2}: 71.76\right), \mathrm{Fe}\left(\mathrm{G}_{1}: 3.37, \mathrm{G}_{2}: 1.94\right), \mathrm{Zn}\left(\mathrm{G}_{1}: 16.28, \mathrm{G}_{2}: 26.76\right), \mathrm{Mn}\left(\mathrm{G}_{1}: 5.61\right.$, $\mathrm{G}_{2}$ : 9.86), $\mathrm{Ni}\left(\mathrm{G}_{1}: 3.57, \mathrm{G}_{2}: 28.33\right)$, and $P\left(\mathrm{G}_{1}: 15.05, \mathrm{G}_{2}: \mathrm{ND}\right)$. The $\mathrm{K}$ levels, reported to aid in the physiological balance of the body, in both varieties were augmented by the soaking of samples in wood ash. Likewise, two varieties (red and yellow) of HS and drinks produced from them were analysed for various nutrients, with both varieties and their drinks found to contain appreciable quantities of nutrients. The authors resolved that HS could be a promising source of iron (800.67-833.00 mg/100 g) and $\beta$ carotene (281.28-285.29 RE/100 g) [89].

It is worth mentioning that, due to the nutritive value of HS, [90] utilised it in a community-based feeding intervention programme in some districts of the Upper East Region of Ghana. The authors concluded that HS feeding (1.9 kg/day) improved iron levels of women of childbearing age, and protected against stunting among toddlers during the dry/lean season. Therefore, employing it in pito fortification would go a long way to curbing some of the mineral deficiency menaces in the general public.

\subsection{Phytochemical Composition}

Recently, [32] assessed HS calyx and its by-products for bioactive compounds and detected phenolic compounds (14.24 $\pm 0.77 \mathrm{GAE} \mathrm{mg} / \mathrm{g})$, flavonoids $(10.37 \pm 0.67 \mathrm{CE} \mathrm{mg} / \mathrm{g})$, and anthocyanins $(5.76 \pm 0.43 \mathrm{mg} \mathrm{C} 3 \mathrm{G} / \mathrm{g})$; however, the concentration in the calyx by-product were lower $(p<$ 0.05 ) by $52.0 \%, 45.7 \%$, and $57.1 \%$, respectively. Further analysis with ultra-performance liquid chromatograph (UPLC) coupled to a quadrupole time-of-flight (QTOF) mass spectrometer (MSE) identified 34 extractable polyphenols, 3 non-extractable polyphenols, and 2 organic acids in calyx and its by-product. Table 4 shows the concentrations of individual phenolics obtained by different extraction assays. Nguyen et al. [91] extracted anthocyanins from HS. In fact, its rich content of anthocyanins (e.g., delphinidin-3-glucoside, delphinidin-3-sambubioside, cyanidin-3-glucoside, and cyanidin-3-sambubioside), which is responsible for its reddish colouration, has placed it in the spotlight as an alternative source of an edible colouring agent to replace the synthetic colouring additives currently being used [92]. $\beta$-sitosterol, ergosterol [93,94], quercetin, luteolin, and its glycoside [95] were also detected in separate studies of HS extracts. Similarly, [96] found an appreciable concentration of quercetin and rutin: $3.2 \mathrm{mg} / \mathrm{g}$ and $2.1 \mathrm{mg} / \mathrm{g}$, respectively. Some important compounds in different HS species have been extensively reviewed [97].

Table 4. Polyphenolics detected in Hisbus sabdariffa.

\begin{tabular}{ll}
\hline \multicolumn{1}{c}{ Phenolics } & Concentration (ppm) \\
\hline Hydroxycitric acid $^{1}$ & $8288.03 \pm 397.63$ \\
\hline Hibiscicus acid $^{1}$ & $31122.02 \pm 1128.39$ \\
\hline Chlorogenic acid isomer I $^{1}$ & $2755.15 \pm 62.42$ \\
\hline Chlorogenic acid $^{1}$ & $1923.72 \pm 38.69$ \\
\hline Chlorogenic acid isomer II $^{1}$ & $1041.19 \pm 16.96$ \\
\hline Myricetin 3-arabinogalactose $^{1}$ & $57.32 \pm 2.51$ \\
\hline Quercetin 3-sambubioside $^{1}$ & $304.02 \pm 5.90$ \\
\hline 5-O-Caffeoylshikimic acid $^{1}$ & $171.47 \pm 6.92$ \\
\hline Quercetin 3-rutinoside $^{1}$ & $495.70 \pm 4.34$ \\
\hline Quercetin 3-glucoside $^{1}$ & $143.74 \pm 2.16$ \\
\hline Kaempferol 3-O-rutinoside $^{1}$ & $91.86 \pm 2.28$ \\
\hline N-Feruloyltyramine $^{1}$ & $98.97 \pm 1.80$ \\
\hline
\end{tabular}


Table 4. Cont.

\begin{tabular}{|c|c|}
\hline Phenolics & Concentration (ppm) \\
\hline Kaempferol 3-(p-coumarylglucoside) ${ }^{1}$ & $28.37 \pm 0.48$ \\
\hline Quercetin $^{1}$ & $121.24 \pm 2.01$ \\
\hline 7-Hydroxycoumarin ${ }^{1}$ & $1839.20 \pm 25.34$ \\
\hline Delphinidin 3-sambubioside ${ }^{1}$ & $2701.21 \pm 165.55$ \\
\hline Cyanidin 3-sambubioside ${ }^{1}$ & $1939.15 \pm 39.27$ \\
\hline Hisbiscus acid hydroxyethylesther ${ }^{2}$ & 235.05 \\
\hline Hisbiscus acid dimethylesther $^{2}$ & 217.04 \\
\hline 2-O-trans-cafeoyl-hydroxicitric acid ${ }^{2}$ & 369.05 \\
\hline Methylepigallocatechin ${ }^{2}$ & 319.08 \\
\hline Ethylchlorogenate $^{2}$ & 381.12 \\
\hline 2-O-trans-feruloyl-hydroxicitric acid ${ }^{2}$ & 263.08 \\
\hline Hibiscus acid hydroxyethyldimethylesther ${ }^{2}$ & 263.08 \\
\hline Coumaroylquinic acid $^{2}$ & 337.09 \\
\hline Cryptochlorogenic acid $^{2}$ & 353.09 \\
\hline Methyl digallate $^{2}$ & 335.04 \\
\hline
\end{tabular}

\subsection{Biological Activities}

\subsubsection{Anti-Inflammatory Effects}

Meraiyebu et al. [100] observed a significant reduction $(p<0.05)$ in paw (carrageenan-induced inflammation) diameter in the group that received a high dose $(500 \mathrm{mg} / \mathrm{kg} \mathrm{b} . \mathrm{w})$ of methanolic extract of HS from $0.566 \pm 0.023$ to $0.414 \pm 0.009$ compared with the control group. Likewise, Obouayeba et al. [101], in a recent study, also showed that $200 \mathrm{mg} / \mathrm{kg}$ body weight of HS aqueous extract significantly inhibited carrageenan-induced paw inflammation in rats compared to the control. The inflammatory activities were ascribed to the phenolic compounds, especially the flavonoids (gossypetin, hibiscetin, quercetin, and sabdaretin), in the extract. Similarly, [102] ascribed the potent anti-inflammatory effects of HS extracts to the phenolic acids, especially trans 3-O-caffeoylquinic acid. However, in an earlier study, [103] documented that HS extract performed poorly when compared to aqueous extracts of Acacia nilotica in the inhibiting (reduction of paw oedema) effect on a carrageenan-induced paw.

\subsubsection{Antioxidant Activities (AOA)}

Using the 1,1-diphenyl-2-picrylhydrazyl (DPPH) radical-scavenging activity, Nguyen et al. [104] reported higher antioxidant activities of cookies supplemented with HS seed powder $(73.98 \pm 1.11 \%)$ compared to the control $(54.04 \pm 0.97 \%)$. In addition, the total phenolics (one of the major groups of compounds responsible for AOA) was found to be high in HS-supplemented cookies $(1.91 \pm 0.07$ mgGAE/g) compared to the control (1.25 $\pm 0.07 \mathrm{mgGAE} / \mathrm{g})$. The antioxidant activity of HS is reported to be concentration dependent. Comparing various concentrations of HS extract, the authors documented the following \% inhibition/scavenging activity of $89.70 \pm 0.639,63.56 \pm 2.132,60.69 \pm 1.350,58.38$ \pm 2.286 , and $57.01 \pm 4.045$ for the concentration $(\mathrm{mg} / \mathrm{mL})$ of $100,50,25,12.6$, and 6.25 , respectively. Though at higher concentrations, the AOA of HS was comparable to that of the standard, it was nonetheless lower compared to the standard. Furthermore, [105] isolated protocatechuic acid (PCA), a simple phenolic compound, from Hibiscus and assessed its protective effects against oxidative damage induced by tertbutylhydroperoxide ( $\mathrm{t}-\mathrm{BHP}$ ) in rat hepatocytes. The results revealed that PCA was 
effective in suppressing indicators of hepatic damage, such as lactate dehydrogenase (LDH) and ALT, at a concentration of $0.05 \mathrm{mg} / \mathrm{mL}(p<0.01$ for LDH; $p<0.05$ for ALT) and $0.10 \mathrm{mg} / \mathrm{mL}(p<0.01$ for LDH and ALT). In addition, PCA significantly inhibited the synthesis of malondialdehyde $(p<0.05$ and $p<0.01$ ), a biomarker of cell injury. The authors concluded that the main mechanism of the AOA is its ability to quench free radicals. The addition of HS extracts to palm wine increased the antioxidant activity of the final products after fermentation [106]. Several other studies have been published on the AOA of various parts of HS [107-113].

\subsubsection{Antidiabetic and Anti-Hypertensive Effects}

With regards to the antidiabetic activity, streptozotocin-induced diabetic mice $(55 \mathrm{mg} / \mathrm{kg}$ ) showed a significant decline in blood glucose after the administration of ethanolic extract of HS (600 or 400 $\mathrm{mg} / \mathrm{kg})$. The reference drug glibenclamide $(0.65 \mathrm{mg} / \mathrm{kg})$ showed a similar trend in lowering the blood glucose levels in diabetic mice [114]. A significant diminution in blood glucose (41-46\%) and insulin levels (14\%) after the oral administration of ethanolic extract of flowers of HS for 21 days on streptozotocin-induced $(60 \mathrm{mg} / \mathrm{kg})$ diabetic Charles Foster strain male albino rats has been reported. In addition, the total serum cholesterol decreased significantly $(p<0.05 ; p<0.001)$ whereas high density lipoprotein (HDL)-cholesterol increased by $12.54 \pm 5.98 \%$ [115]. Similar findings have been reported by [116]. Mozaffari-Khosravi et al. [117] carried out a randomised double-blind controlled trial to compare the potential anti-hypertensive efficacy of sour HS (ST) and black tea (BT) on 60 diabetic patients with mild hypertension not taking antihypertensive or antihyperlipidemic medicines. The findings revealed that the mean pulse pressure (PP) of the patients in the ST group decreased from 52.2 \pm 12.2 to $34.5 \pm 9.3 \mathrm{mmHg}(p<0.001)$, whereas an increase from $41.9 \pm 11.7$ to $47.3 \pm 9.6 \mathrm{mmHg}(p<0.01)$ was observed in the BT group. With respect to the systolic BP (SBP), the ST group showed a decrease from $134.4 \pm 11.8$ to $112.7 \pm 5.7 \mathrm{mmHg}$ after 1 month ( $p$-value of 0.001 ); however, an elevation (from $118.6 \pm 14.9$ to $127.3 \pm 8.7 \mathrm{mmHg}$ ) was observed in the BT-treated group. In this regard, ST had positive effects on blood pressure in type II diabetic patients with mild hypertension. Likewise, McKay and colleagues conducted a randomized double-blind placebo-controlled clinical trial on 65 pre- and mildly hypertensive adults aged 30-70 years not taking blood pressure (BP)-lowering medications with brewed HS tea and a placebo beverage for 6 weeks. The results demonstrated that daily intake of HS teas lowered the BP of pre- and mildly hypertensive adults [118]; thus, it could be used in an intervention for folks with these conditions. According to the literature, the anti-hypertensive activity of HS extracts could be attributed to the inhibition of angiotensin-converting enzymes (ACEs), acetylcholine-like and histamine-like mechanisms, diuretic effect, reduction in the diffusion distance between capillaries and myocytes, as well as new vessel formation and direct vaso-relaxant effects [19,119-124].

In addition, Huang et al. [125] showed that herbal extracts of HS were effective in reducing high-glucose-stimulated cell proliferation and migration in a dose- and time-dependent manner. The proliferating cell nuclear antigen (PCNA) and matrix metalloproteinase (MMP)-2 activation were roundly suppressed by the extracts. Conclusively, the authors suggested that the extracts of HS may potentially be used as adjuvant herbal therapy for managing diabetic patients.

\subsubsection{Biocidal Activities}

The biocidal activities of HS extracts have widely been acclaimed by several researchers. Puro et al. [126] found that aqueous extract of HS at a concentration $(\mathrm{mg} / \mathrm{mL})$ of 100,50 , and 25 was able to inhibit the growth of S. aureus, E. coli, and Klebsiella pneumoniae. In a similar study, [127] demonstrated the antimicrobial action of HS extracts on E. coli strain O157:H7, a major bacterial foodborne pathogen isolated from food, veterinary, and clinical samples. The authors concluded that extracts of HS were effective at all tested concentrations in inhibiting the growth of bacteria, and thus could be used as a source of bioactive compounds as well as a biocidal agent. Recently, [102] showed the biocidal activities of HS extracts (hydroethanolic and infusion extracts) on various important bacterial and fungal species. They found a higher minimum inhibitory concentration (MICs) against 
Micrococcus flavus, S. aureus, Listeria monocytogenes, P. aeruginosa, and Salmonella typhimirium in both extracts. Nevertheless, Bacillus cereus, Trichoderma viride, and Aspergillus ochraceus showed lower MIC values for both extracts. Conclusively, both extracts exhibited good antibacterial and antifungal activity in comparison with a control.

A recent study revealed that hydroethanolic extract of HS was effective against all test fungi (Aspergillus fumigatus, Aspergillus versicolor, Aspergillus ochraceus, Aspergillus niger, Trichoderma viride, Penicillium funiculosum, Penicillium ochrochloron, Penicillium verrucosum var. cyclopium) compared to an infusion extract. In addition, $\mathrm{T}$. viride showed resistance to the extracts (MIC $=0.075$ and minimal fungicidal concentration $(\mathrm{MFC})=0.15 \mathrm{mg} / \mathrm{mL}$ ). The authors ascribed the fungicidal activity to the different concentrations of phenolic compounds identified in the extracts [92].

\subsection{Toxicological Aspect}

Fakeye and co-workers orally administered an extract of HS obtained by different solvents (water, $50 \%$ ethanol, or ethanol) to male Charles Foster rats in the quest to elucidate their toxicity levels. They reported that rats fed with a lower dose of $300 \mathrm{mg} / \mathrm{kg}$ of aqueous or $50 \%$ ethanol extracts exhibited a loss of fur in the first 3 days after treatment. The groups administered with $50 \%$ ethanol and aqueous extracts died by 40 and 60 days, respectively. In contrast, all of the group fed with 100\% ethanol extract survived. Additionally, a significant reduction in the erythrocyte count in all groups was observed. The results revealed that while higher doses of aqueous and 50\% ethanol extracts significantly increased the level of AST, all extracts increased (significantly) ALT and creatinine levels, with a more prominent increase in the creatinine level observed in aqueous extracts. The authors concluded that aqueous extracts caused an increase in serum creatinine whereas $50 \%$ ethanol had profound effects on liver function enzymes (biomarkers for liver damage) and creatinine levels [128]. In a recent study, [102] observed that hydroethanolic extract of HS had a significant toxicity effect on cervical carcinoma cells (HeLa; $250 \pm 13$ GI $_{50}$ ) compared to an infusion extract (321 $\left.\pm 9 \mathrm{GI}_{50}\right)$. Moreover, the hydroethanolic extract also showed substantial activity (321 $\left.\pm 9 \mathrm{GI}_{50}\right)$ against hepatocellular carcinoma (HepG2) compared to an infusion extract $\left(>400 \mathrm{GI}_{50}\right)$. However, none of the extracts were harmful to the non-tumour cell line (PLP2, porcine liver cells), even with the maximal tested concentration $(400 \mu \mathrm{g} / \mathrm{mL})$. Liver and kidney indices (AST, ALT, ALP, and direct bilirubin) significantly increased, indicating organ dysfunction, when 1-5 g/kg of calyx extracts of HS was fed to rats. Furthermore, at dose levels of 2 , 3,4 , and $5 \mathrm{~g} / \mathrm{kg}$, the levels of creatinine, urea, and uric acid increased significantly compared to the control group [129]. Conversely, [130] reported that extracts of HS did not manifest acute toxicity in Sprague-Dawley (SD) rats even at an amount of $5000 \mathrm{mg} / \mathrm{kg}$ body weight. This study showed the potential safety (virtually non-toxic) of HS, hence it could be utilized in the food industry. Similar results were reported by [131]. Gaya et al. [132], after orally administering varying doses of HS seed extract for six days, observed acute toxicity $\left(\mathrm{LD}_{50}\right)$ only above $5000 \mathrm{mg} / \mathrm{kg}$. Additionally, the average intake of 150-180 mg/kg/day of an aqueous-ethanol extract of HS calyces appeared to be safe, but higher doses may result in liver damage [133]. Obouayeba and colleagues [101] found no LD 50 nor death of rats after $24 \mathrm{~h}$ of administration of HS extracts ranging from 250 to $2000 \mathrm{mg} / \mathrm{kg}$ of body weight.

From the above literature, it can be concluded that depending on the dose and specific parts of HS consumed, toxicity may result; however, in general, HS is safe for consumption and the fortification of food.

\section{Brewing Processes with Tetrapleura tetraptera and Hibiscus sabdariffa (Malvaceae)}

\subsection{Indigenous Malting, Wort Production, and Fermentation}

The entire process of brewing bioactive pito is summarised in Figure 3. Sorghum or millet could be sourced from the local market or from a farmer. Broken kernels and debris (unwanted materials) would then be removed manually by winnowing. The clean grains could then be steeped in water $(10 \mathrm{~L})$ at $25^{\circ} \mathrm{C}$ for $24 \mathrm{~h}$. The water of steeped grains would be drained off, and the soaked grain spread 
in a jute sack while another is used to cover it. Water is then sprinkled on the sack to provide enough moisture for germination of the grains. This is vital for enzyme synthesis (amylases, proteases, etc.), which are necessary for starch conversion during mashing. The grains could be germinated at $30{ }^{\circ} \mathrm{C}$ for 4 days, followed by kilning (sun drying for 3 days). The shoots and rootlets could be removed manually; however, this step is usually not carried out by indigenous brewers. The dried malt would then be milled into flour. An amount of $6.9 \mathrm{~kg}$ of milled malt ( $70 \%$ sorghum and $30 \%$ millet) could be mixed with hot water (about $53{ }^{\circ} \mathrm{C}$ ) and allowed to rest for $30 \mathrm{~min}$ in order to gelatinize malt starch. The timing at this stage would vary depending on the brewer/producer. In the traditional setting, the milled malt is usually mixed with warm water on a fire and stirred for about $30 \mathrm{~min}$. Other cereal grains could be utilized as alternative malts sources. It is worth mentioning that these local producers do not consider the size of the milled malt as in western brewer practice. Therefore, there are always issues with the filtration process. To curb the menace of filtration, the brewers employ 'yolga' (Figure 4) during the mashing to produce less viscous wort, thus it flows easily through the more compacted mash bed (Figure 5). Indigenous brewers always leave the mash overnight to enhance gelatinization and cooling. After cooling (the next day), the mash would be brewed according to the following mashing program: $63^{\circ} \mathrm{C}$ for $60 \mathrm{~min}, 75^{\circ} \mathrm{C}$ for $90 \mathrm{~min}$, and cooled to $30^{\circ} \mathrm{C}[1,35,134,135]$. The mash could then be poured in a millet stalk woven basket for filtration (Figure 5). Rice husk could be added to enhance filtration. The obtained wort (hazy due to insufficient filtration) is then boiled for several hours. Ten minutes before the end of boiling, an amount of $10 \mathrm{~g}$ each of HS and prekese could be added to the boiled wort. This would aid extraction of the bioactive as well as the aroma compounds, thus bolstering the nutritional profile and aroma of the final pito (Figure 6). Another option would be to extract the bioactive and aroma compound via infusion, with water as the solvent. The solution could then be added to the boiling wort. In this case, ethanolic extraction is not recommended because ethanol could inhibit the growth and acclimatization of the yeast, thus causing stuck fermentation. The physicochemical properties of HS extract, must, and wine are reported in Table 5.

Table 5. Physico-chemical parameters of different Hibiscus sabdariffa extracts, must, and wine according to the literature.

\begin{tabular}{cccc}
\hline Parameters & Extract & Must & HS wine \\
\hline oBrix & $2.00 \pm 0.02^{\mathrm{a}}$ & $1600 \pm 0.02^{\mathrm{a}}$ & $4.90 \pm 0.02^{\mathrm{a}}$ \\
& $2.50 \pm 0.02^{\mathrm{b}}$ & $22.00 \pm 0.20^{\mathrm{b}}$ & $5.10 \pm 0.01^{\mathrm{b}}$ \\
\hline $\mathrm{pH}$ & $3.78 \pm 0.03^{\mathrm{a}}$ & $3.72 \pm 0.04^{\mathrm{a}}$ & $3.43 \pm 0.04^{\mathrm{a}}$ \\
& $2.34 \pm 0.14^{\mathrm{b}}$ & $3.76 \pm 0.08^{\mathrm{b}}$ & $3.57 \pm 0.02^{\mathrm{b}}$ \\
\hline Colour (visual) & Deep red ${ }^{\mathrm{a}, \mathrm{b}}$ & $\begin{array}{c}\text { Deep red }^{\mathrm{a}} \\
\text { Dull red }^{\mathrm{b}}\end{array}$ & Brilliant rose $^{\mathrm{a}, \mathrm{b}}$ \\
\hline Alcohol (\% $w / v)$ & $0.00^{\mathrm{a}, \mathrm{b}}$ & $0.00^{\mathrm{a}, \mathrm{b}}$ & $10.80 \pm 0.08^{\mathrm{a}}$ \\
\hline Ash $(\%)$ & $0.70 \pm 0.05^{\mathrm{a}}$ & $0.68 \pm 0.02^{\mathrm{a}}$ & $0.43 \pm 0.04^{\mathrm{a}}$ \\
\hline Total anthocyanins $(\mathrm{abs} / \mathrm{mL})$ & $28.43 \pm 0.04^{\mathrm{a}}$ & $28.30 \pm 0.10^{\mathrm{a}}$ & $22.65 \pm 0.08^{\mathrm{a}}$ \\
\hline Crude protein $(\%)$ & $2.63 \pm 0.23^{\mathrm{a}}$ & $4.21 \pm 0.26^{\mathrm{a}}$ & $1.75 \pm 0.09^{\mathrm{a}}$ \\
\hline Ascorbic acid $(\mathrm{mg} / 100 \mathrm{~mL})$ & $1.12 \pm 0.06^{\mathrm{a}}$ & $1.06 \pm 0.14^{\mathrm{a}}$ & $0.6 \pm 90.13^{\mathrm{a}}$ \\
\hline Sulphur dioxide $(\%)$ & $0.00^{\mathrm{a}}$ & $13.40 \pm 0.12^{\mathrm{a}}$ & $10.50 \pm 0.06^{\mathrm{a}}$ \\
\hline & ${ }^{\mathrm{a}}[29]^{\mathrm{b}}[25]$. & &
\end{tabular}




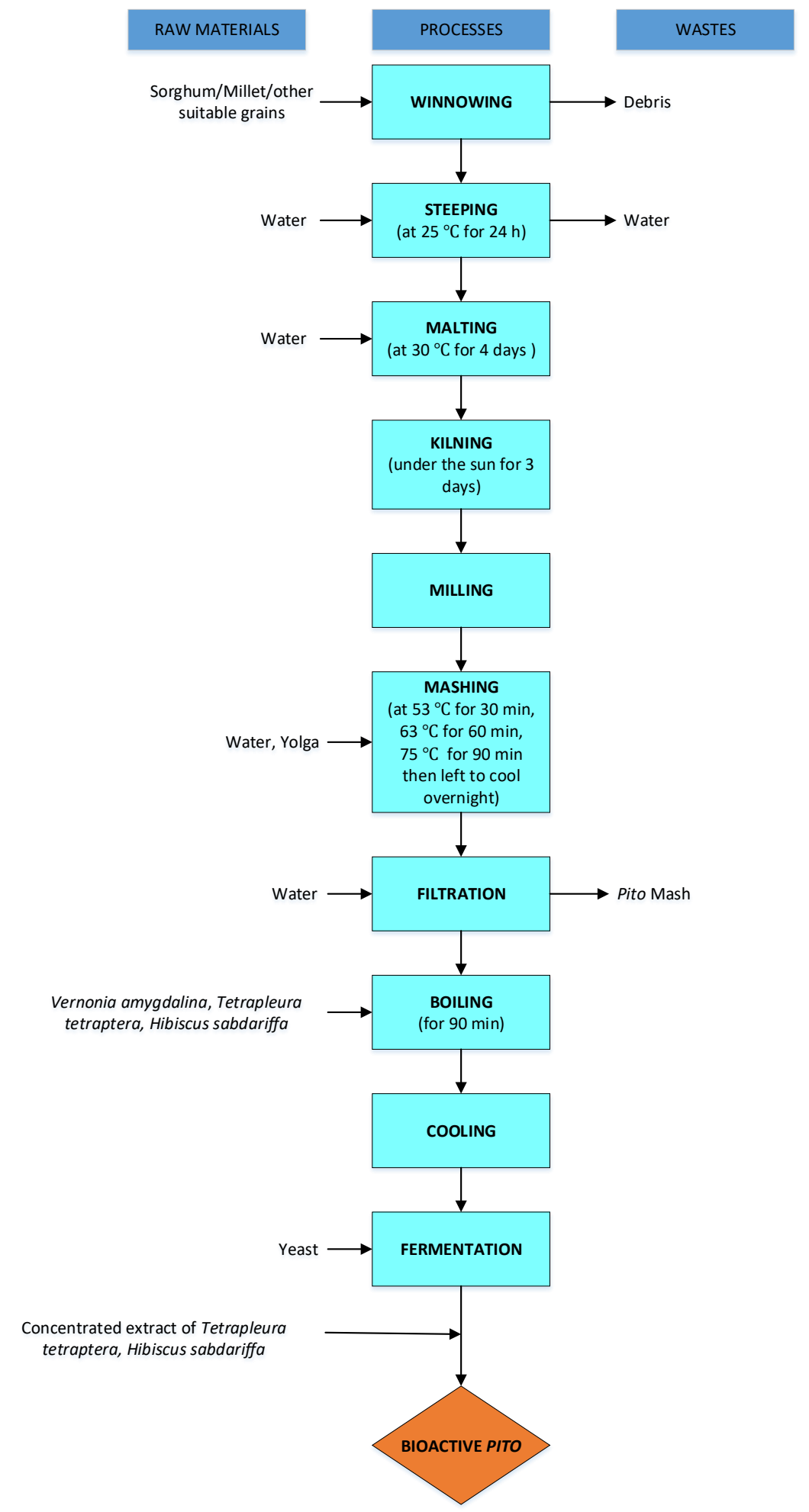

Figure 3. Flow chart of bioactive pito production. 


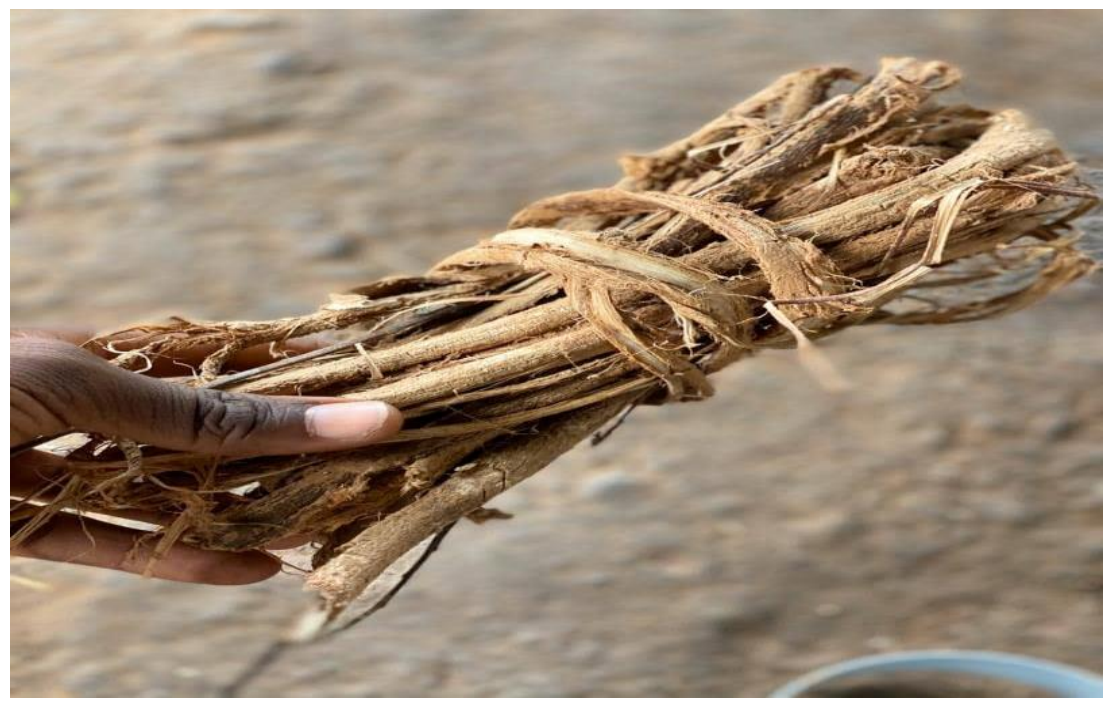

Figure 4. A typical Ghanaian 'yolga' used in brewing pito.

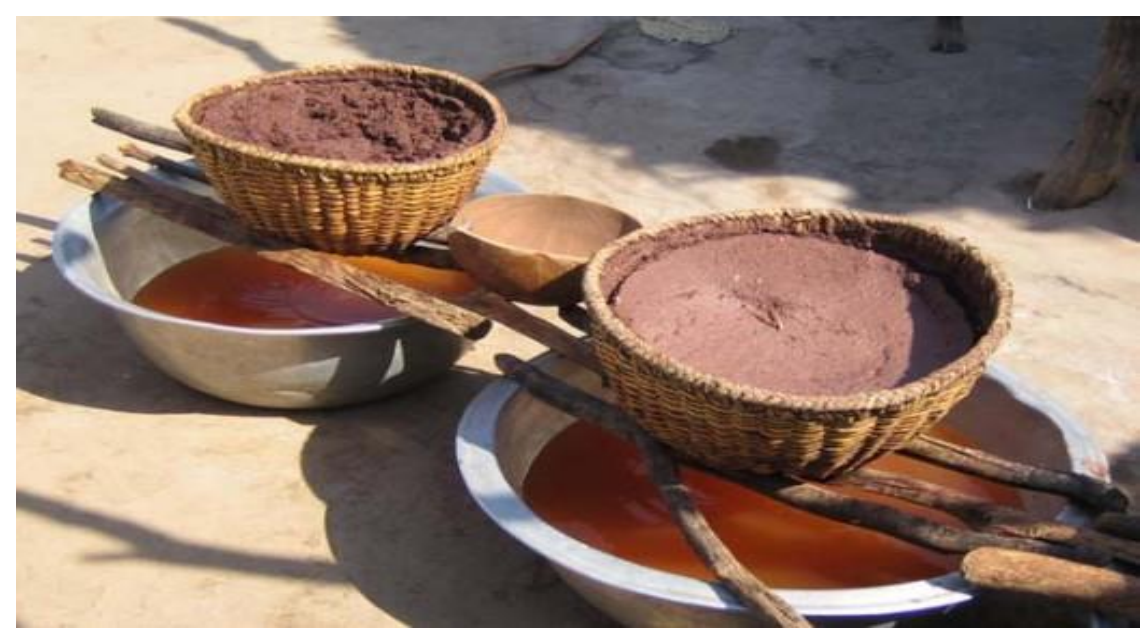

Figure 5. Indigenous method of lautering [136].

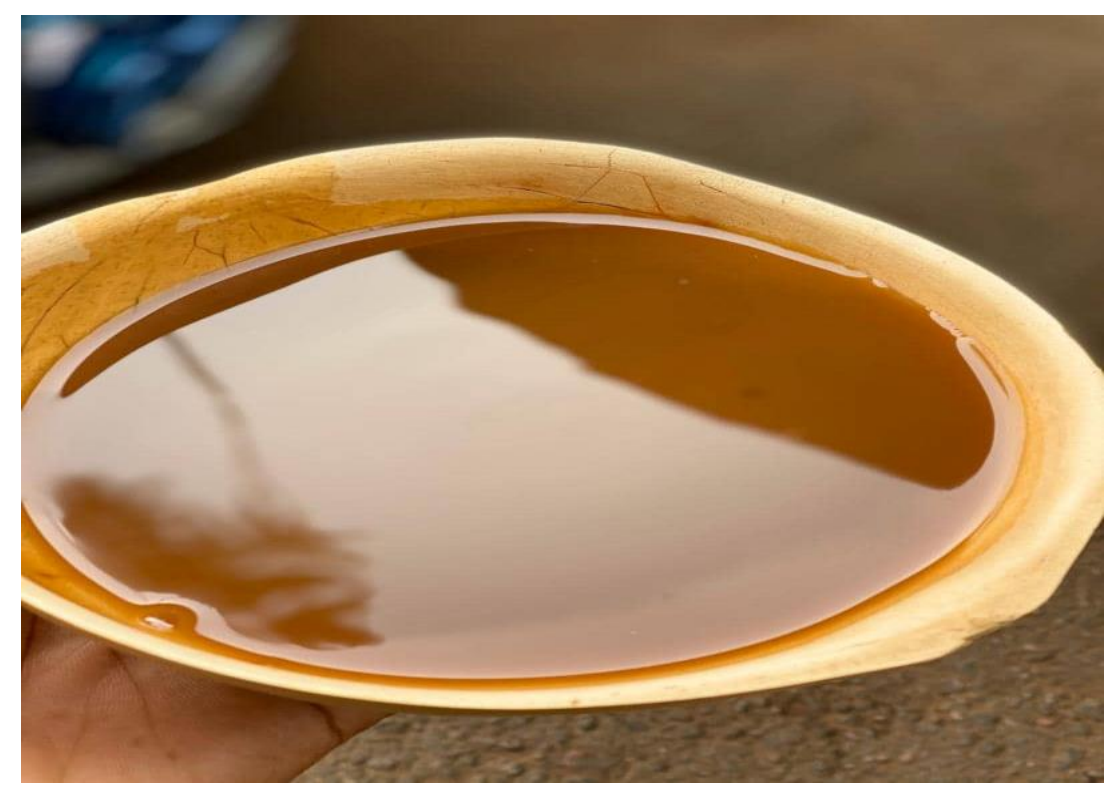

Figure 6. Pito served in calabash. 
According to [137], the leaves of Vernonia amygdalina (2 g/L) could be added $10 \mathrm{~min}$ before the end of boiling. V. amygdalina, also known as bitter leaf, is a woody shrub known in the northern part of Ghana as 'swaka'. Aside from being consumed as a leafy vegetable, it has been used therapeutically in several countries in Africa to treat gastrointestinal problems, microbial and parasitic infections, as well as diabetes [138]. Since indigenous brewers do not usually add hops (Humulus lupulus) during wort boiling, $V$. amygdalina could serve as hops, providing a tint of bitterness to the brewed pito. Extracts of $V$. amygdalina have been found to exhibit potent antimicrobial and antioxidant activities due to its low $\mathrm{pH}$ and higher phenolic compounds, respectively [139-142]. Gas chromatography-mass spectroscopy (GC-MS) analysis of V. amygdalina ethanolic leaf extract revealed overwhelming evidence of flavour compounds, such as 4-methyl-vinyl butyrate, 2,3-pentanedione, ethyl ester-9,12- octadecadienoic acid [142], etc.; therefore, it could enhance the flavour of the pito. The high concentration of phenolics in $V$. amygdalina could also enhance the antioxidant activities of the brewed pito in addition to other bioactive ingredients originating from the other raw materials (i.e., T. tetraptera and H. sabdariffa, sorghum, or millet). Since hops are expensive and not easily available for local pito brewers in Africa, replacing it with $V$. amygdalina could be a cheaper alternative, though hops would be superior to $V$. amygdalina. Consequently, the contribution of $V$. amygdalina in terms of antimicrobial activities, bitterness, antioxidant activities, etc. to brewed pito would impart good taste and make it safe for consumption.

The boiled wort is usually left to cool overnight, followed by pitching with yeast slurry or the dried form obtained from a previous batch of spontaneous fermentation. In some cases, the wort is pitched with yeast from a previous fermentation (backslopping) somehow entrapped on the jute sack. It usually takes $24 \mathrm{~h}$ or less for the fermentation to complete. It is worth mentioning that the concentration of biocidal compounds resulting from the addition of plants (HS and TT) before fermentation would not be enough to hinder the fermentation by the yeast; nonetheless, further research into it is required. The functional pito could then be served. Secondary fermentation/carbonation is not practiced by traditional/indigenous brewers. Due to the spontaneous fermentation involved in pito production, [5] isolated 70 yeast species belonging to either Saccharomyces cerevisae, Candida inconspicua, Issatchenkia orientalis, as well as Lactobacillus fermentum, Lactobacillus buchneri, and Lactobacillus sp. Extracts of HS, prekese, and V. amygdalina could augment the yeast nutrition in the wort for rapid and smooth fermentation. This may improve and give the final pito consistent flavour because of sufficient nutrients in the wort, and thus better synthesis of the flavour compounds. In western brewing, brewers always add calcium chloride and gypsum, among other minerals, to improve the nutrition, thus providing the yeast with all the minerals required for ideal fermentation; however, this is not practiced by local brewers of pito. Proximate analysis of the HS, V. amygdalina, and prekese revealed that these materials contain substantial amounts of these minerals, and thus could indirectly provide the yeast with the necessary nutrition [142]. Concentrated extracts could be incorporated after fermentation to enhance the biocidal activity of the suspending yeast, which later causes sourness and spoilage of the beer (for more details, see Section 8).

\subsection{The Fate of Bioactive Compounds during Brewing}

Brewing processes (mashing, wort filtration, fermentation) affect the concentration of bioactive compounds in the final beer. The polyphenol (flavonoids, non-flavonoids, tannins, and nontannins) content was significantly high in all malt worts compared to adjunct worts (malt and maize) after mashing, and decline during lautering. Interestingly, the concentration starts to increase during wort boiling and drops significantly during fermentation [143]. It was speculated that the yeast absorbed any phenols released, and hence a decrease in concentration is observed during and after fermentation [144]. Similarly, Pascoe and colleagues [145] observed a significant increase in some phenolics (i.e., catechin, ferulic, vanillic, chlorogenic, and $p$-coumaric acid) from mashing to wort boiling. Processes, such as wort dilution, fermentation, and warm rest, had no effect on most phenolics; however, they resulted in a significant decrease of ferulic acid after warm rest. Using the $\mathrm{ABTS}^{\bullet+}$ scavenging activity and 
FRAP assay, the authors reported a significant increase in the antioxidant activity of samples at various stage of brewing. Precisely, ABTS $^{\bullet+}$ scavenging activity showed that fermentation had increased the AOA and later declined during warm rest. Recently, Koren et al. [146] reported that fermentation had no significant effects on the evolution of antioxidant activity. However, other brewing activities considerably increased AOA.

Fermentation was found to increase the concentration of some free phenolic acids (protocatechuic acid, 3-OH-benzoic acid, vanillic, caffeic, $p$-coumaric, sinapic) in perła beer. A decrease in other phenolics (ferulic, 4-OH-benzoic, chlorogenic, syringic, o-coumaric) due to fermentation was also observed, and their concentration was less in final beer compared to the wort [147]. Solid-state fermentation of kidney beans by B. subtilis CECT 39T (ATCC 6051) enhanced the concentration of phenolic compounds (31-36 mg/g) and the antioxidant activity (508-541 $\mu \mathrm{g}$ trolox equivalents/g) of the extract. Similarly, the liquid-state fermentation of the same subtract by L. plantarum CECT 748T (ATCC 14917) revealed that the extract possesses potential antihypertensive activity due to its overwhelming concentration of $\gamma$-aminobutyric acid (GABA) $(6.8-10.6 \mathrm{mg} / \mathrm{g})$ and angiotensin-converting enzyme inhibitory (ACEI) activity (>90\%) [148]. The interactions between starter enzymes and the bioactive compound during fermentation led to an increase in phenolics and AOA of fermented kombucha tea extracts. Interestingly, fermented extracts exhibited increased anti-inflammatory potential as well as antiproliferative activity against human breast cancer (MCF-7) and human colon cancer (HCT-116) cells compared to the control (non-fermented tea) [149]. Lastly, [150] reported that the fermentation of vegetables as well as cereal and legumes enhanced the bioaccessibility of other compounds (i.e., vitamins and exopolysaccharides), with a concomitant elevation of AOA in vivo and in vitro. From the literature, it can be concluded that fermentation may enhance the bioavailability of bioactive compounds as well as the other biological functions of TT and HS. However, research ought to be carried out to ascertain the exact effects of fermentation on extracts of HS and TT.

\subsection{Encapsulation of Bioactive Compounds for Brewing Bioactive Pito (Scientific Outlook)}

Recently, [91] evaluated the feasibility of encapsulating anthocyanins from Hibiscus sabdariffa in active yeasts. After optimization, promising results were obtained: An encapsulation efficiency (EE) and yield of $27 \%$ and $208 \mu \mathrm{g} / 100 \mathrm{mg}$ of cells, respectively, were reported. The percentage loss of colour was lower in conditions of low enzymatic activity: $3.1 \%$ at $5{ }^{\circ} \mathrm{C}$ for non-heat-treated cells in water. The $\mathrm{pH}$ of the buffer influenced the degradation of encapsulated anthocyanin. The degradation of non-heat-treated cells decreased strongly to $9.4 \%$ compared to $36.5 \%$ in water. Their findings prove that yeast cells are ideal capsules for encapsulating bioactive substances, which could be incorporated during the brewing of bioactive high-flavour pito. Moreover, it has been reported previously $[9,151,152]$ that yeast possess the ability to bioaccumulate and biotransform materials into a bioavailable form in beverages.

Surface response methodology was applied to optimize conditions for the encapsulation of bioactive compounds extracted from Yanang (Tiliacora triandra). Depending on the ratio of the core material, the bioactive compounds were altered; thus, an ideal core shell is required to protect bioactive ingredients adequately. The encapsulation process did not cause a loss of active ingredients [153]. Edible coatings could be utilized as encapsulating matrices for bioactive and aroma compounds, which may improve the functionality and high sensory performance of the product (pito) [154].

From the above studies, there is a possibility of encapsulating bioactive and flavour compounds extracted from HS and prekese, which would be incorporated in the final pito. However, this strategy would never be feasible for indigenous brewers. Encapsulated bioactive and flavour compounds could be added to the pitched wort before or after primary fermentation. Fermentation could enhance the bioavailability of the ingredients; however, research ought to be conducted in order to verify this hypothesis. 


\subsection{Pito Characterization}

\subsubsection{Colour}

According to [6], the colour of brewed pito ranges from golden yellow to dark brown, which depends on the sorghum, millet, or maize used. Different cultivars of cereals show different grain colours, which will later alter the hue of the final beer. The incorporation of HS and prekese would change the hue of the final beer to either light red or deep red owing to the extract of HS. As reported earlier, the hue of locally produced gin infused with prekese ranged from light green to deep brown, which seems to enjoy a higher patronage [34]; therefore, brewed pito could take a similar hue. However, the colour of HS could mask it, hence the colour of the HS would be reflected in the final product instead. In addition, the colour of wine produced from HS calyx extract was brilliant red $[25,29]$.

During the fermentation of pito with single starter culture (SSC) and mixed starter culture (MSC), it was discovered that after $48 \mathrm{~h}$ of fermentation, wort pitched with MSC registered higher European Brewery Convention (EBC) units compared to SSC fermentation. A decrease was observed at $72 \mathrm{~h}$ from $50 \pm 3$ to $42.3 \pm 3.78$ and $50 \pm 3$ to $34 \pm 3.60 \mathrm{EBC}$ units for SSC and MSC, respectively, followed by a sharp decline. The increase in EBC units was ascribed to the rapid fermentation occurring after $48 \mathrm{~h}$, resulting in the accumulation of yeast metabolites [1]. However, when fermentation was completed, the yeast flocculate left a clearer beer. Recently, [155] reported the colour (EBC) of pito obtained from pure cultures (Lactobacillus delbrueckii and S. cerevisiae) and a traditional mixed starter to be $45.6 \pm 0.9$ and $50.7 \pm 0.2$, respectively. The uncontrolled fermentation due to the mixed population of inoculum pitched could be attributed to the higher colour. However, the grit size, filtration bed, and efficiency of mashing could also affect the colour of the wort, and subsequently, the final beer. Currently, the reliable and most used method in quantifying beer colour is proposed by the European brewery convention, which basically involves degassing the beer and filtering it through a membrane filter (Milipore HA $0.45 \mu \mathrm{M})$. The filtrate is then measured at an absorbance of $430 \mathrm{~nm}$ with a spectrophotometer whilst using distilled water as the blank. The colour is then estimated using Equation (1):

$$
\mathrm{C}=25 \times \mathrm{F} \times \mathrm{A}_{430},
$$

where $\mathrm{C}=$ colour, in $\mathrm{EBC}$ units; $\mathrm{F}$-dilution factor; $\mathrm{A}_{430}=$ absorbance at 430 ; and $25=$ is the multiplication facto.

The colour units of EBC could be converted to the standard reference method (SRM) using the equation below:

$$
\mathrm{SRM}=\mathrm{EBC} \times 0.508 .
$$

\subsubsection{Alcohol Content (ABV)}

The ethanol concentration is very important for the mouth feel and flavour of alcoholic beverages [156]. According to [157], the rate of ethanol synthesis depends on the type of sorghum utilised in the production of wort. They reported a rapid production of ethanol in wort produced from white sorghum compared to red sorghum. A positive correlation was also established between the yeast growth and ethanol production; consequently, rapid cell growth in white sorghum wort led to a faster ethanol production rate compared to red sorghum wort. The varying concentration of the ethanol content of pito, as reported in Table 6, could be attributed to the above theory; nonetheless, other factors, such as the concentration (number) of yeast pitched, initial Plato, aeration, nutritional composition, fermentation temperature, etc., are partly linked to the difference in ethanol as reported by the authors. The addition of T. tetraptera and H. sabdariffa (either extracts or whole) may increase the degree Plato of the wort, consequently increasing the ethanol content of the final beer. Yeboah-Awudzi [158] reported ${ }^{\circ}$ Brix that ranged from $7.60 \pm 0.01$ to $14.7 \pm 0.20$ in various sobolobo samples sourced from Kumasi, Ghana; hence, the addition of infusion extracts of HS and TT would elevate the wort ${ }^{\circ}$ Brix. It is worth mentioning that the amount of sugar in a natural beverage of HS is less than what is reported in the 
above study ([158]); however, different producers add sugars to sobolobo, accounting for the higher ${ }^{\circ}$ Brix documented. Surprisingly, higher ${ }^{\circ}$ Brix $(22.00 \pm 0.20,16.00 \pm 0.02)$ was reported in various must samples (extracted from HS to produce local red wine) [25,29]. A handheld density meter is the cheapest and easiest method that indigenous brewers could adopt to quantify alcohol in pito since it does not require any technical know-how as compared to complex methods like gas chromatography, high performance liquid chromatography (HPLC), potentiometry, etc. The percentage of ethanol could be estimated (from the equation below) when the initial and final gravity of the wort/ferment is known:

Alcohol by volume $(\mathrm{ABV}(\%)=($ Initial gravity - Final gravity $) \times 131.25$.

Table 6. Alcohol concentration of various pito obtained from the literature.

\begin{tabular}{|c|c|}
\hline Ethanol Content & Author \\
\hline $\begin{array}{l}4.54 \pm 0.04^{£ \%} \% \mathrm{ABV}(\mathrm{SSC}) \\
4.5 \pm 0.03^{\dagger} \% \mathrm{ABV}(\mathrm{MSC})\end{array}$ & [1] \\
\hline $3.93 \% \mathrm{ABV}$ & [159] \\
\hline $2.2 \pm 0.46 \%(v / v)$ & [5] \\
\hline $\begin{array}{c}2.78 \pm 0.02 \% \mathrm{ABV}(\mathrm{SSC}) \\
2.73 \pm 0.01 \% \mathrm{ABV}(\mathrm{MSC})\end{array}$ & [160] \\
\hline $\begin{array}{l}2.30 \times \%(v / v) \\
3.10^{\alpha \%} \%(v / v)\end{array}$ & [161] \\
\hline $\begin{array}{c}4.2 \pm 0.3^{+o} \%, v / v \\
3.6 \pm 0.1^{£}\end{array}$ & [155] \\
\hline
\end{tabular}

$\times$ obtained from $100 \%$ sorghum; ${ }^{\alpha}$ obtained from $70 \%$ sorghum and $30 \%$ finger millet; ${ }^{\dagger}$ obtained from mixed culture;

${ }^{£}$ obtained from Pure culture.

For instance, if the initial and final gravity of the wort/ferments are 1.104 and 1.041, respectively, the pito is approximately $8.27 \%$ alcohol by volume.

\subsection{3. $\mathrm{pH}$}

Adjusting the mash $\mathrm{pH}$ is critical for enzymatic bioconversion of sorghum carbohydrate in to simple/fermentable sugars for yeast to consume and produce ethanol in the final pito. Unlike in western brewing, where calcium carbonate (to raise $\mathrm{pH}$ ) or calcium sulfate/calcium chloride (to lower $\mathrm{pH}$ ) are utilised, this is not practiced by local brewers during the mashing of sorghum grains, resulting in worts with a lower $\mathrm{pH}$. Bamforth [162] reported the $\mathrm{pH}$ optima for malt enzymes and its impact in the mashing and mouth feel of the final beverage. The $\mathrm{pH}$ of wort and pito was documented as $3.62 \pm 0.01(0 \mathrm{~h}$ ) and $3.43 \pm 0.01$ (72 $\mathrm{h}$ for single starter) and $3.50 \pm 0.01$ (72 $\mathrm{h}$ for mixed starter), at the start and end of fermentation [160]. A decrease in $\mathrm{pH}$ from $5.8 \pm 0.1$ to $4.6 \pm 0.1$ was observed by [162] before adding sea buckthorn into the green beer for further fermentation. As reported [162], the drop in $\mathrm{pH}$ is a result of the release of acids by the yeast coupled with the utilisation of buffering materials (free amino nitrogen) in the wort. The wort $\mathrm{pH}$ can influence yeast growth, flocculation, flavour production, etc. The final $\mathrm{pH}$ of pito (untreated) used by [159] in their experiment was 3.2, which is lower than most western beers with the exception of Weisse Beer. The lower $\mathrm{pH}$ of pito could be ascribed to spontaneous fermentation, leading to the rapid release of hydrogen ions by the yeast. Attchelouwa et al. [163] documented $3.2 \pm 0.1$ as the final $\mathrm{pH}$ of Ivorian Sorghum Beer. The inclusion of extracts or whole prekese and HS (boiled in wort) could lead to a drop in the $\mathrm{pH}$ of wort due to the overwhelming phytochemicals present, hence it should be adjusted with buffers, such as calcium carbonate and calcium sulfate/calcium chloride, before pitching. The $\mathrm{pH}$ of the final pito documented by [164] is similar to the values reported earlier. A pocket-sized handheld $\mathrm{pH}$ meter is the ultimate easier method that local brewers could adopt in measuring the $\mathrm{pH}$ of the mash, wort, and final beer. 


\subsubsection{Volatile Compounds}

The flavour of pito is one of the many factors influencing consumers' acceptance and patronage; therefore, it is essential to detect and quantify the aroma and flavour compounds in pito before putting it out for sale. This is critical when it comes to western beer; nevertheless, it is also vital with indigenous products as well, although traditionally, these compounds are not measured. Thirty volatiles were detected and quantified in pito using solid-phase microextraction (SPME) and gas chromatography-mass spectrometry (GC-MS), including 14 esters, 6 alcohols, 3 acids, 3 aldehydes, 2 phenols, and 2 alkanones/ketones [165]. Similarly, [137] identified a total of 55 volatile compounds in pito brewed by Rwandese peasants and a laboratory-brewed pito with and without the addition of $V$. amygdalina. Among the volatiles detected, 28 were esters, 12 alcohols, 9 carbonyls, and 6 acids. The authors concluded that $V$. amygdalina contributed significantly to the overall flavour and aroma of beer, hence it could be a substituent of hops in tropical countries. When the unorthodox method was used to brew pito, a total of 22 volatiles were detected and quantified, which included 11 esters, 3 alcohols, and 8 acids. The study revealed that more volatiles were detected after the secondary fermentation [1]. In another study, 4 esters, 3 aldehydes, 2 fatty acids, and 3 alcohols and diacetyls were identified [160]. Sensory evaluation of pito brewed with a pure yeast culture and dembila revealed that the panellists found no difference in their overall liking between the two products; however, the pure culture enhanced the flavour. The authors concluded that the pure starter culture could be utilized to facilitate scaled-up pito production [164]. Lyumugabe et al. [166] reported that hopping wort with $V$. amygdalina leaves resulted in the synthesis of polyfunctional thiols; however, it inhibited the production of 2-sulfanylethanol and 2-sulfanylethyl acetate. The authors suggested a further study to elucidate the impact of V. amygdalina on the Ehrlich pathway, which leads to the synthesis of cysteine and cysteine-derived thiols. The addition of preseke may contribute fatty acids to the wort, which the yeast could assimilate and store in specialized organelles, the so-called lipid droplets (LD), though fatty acids could also be obtained from different routes as well as de novo synthesis, and the turnover of lipids [167]. It was documented that the rate of acetate ester synthesis depends on the concentration of acetyl coenzyme A (acetyl-CoA) and a fusel alcohol, and the total activity of enzymes involved in the formation and breakdown of the respective ester [168]. Moreover, [169] clearly explained the biosynthesis of fatty acids and their relationship with medium-chain fatty acid ester formation. In a nutshell, the extracts would enhance the flavour generation by supplementing yeast with more/sufficient acetyl-CoA. It is obvious that the present study may present a highly flavoured beer due to the potent volatiles originating from the V. amygdalina, prekese, and HS, coupled with other fermentable metabolites. Therefore, the product would be acceptable to traditional folks.

\subsubsection{Antioxidant Activity}

The AOA of prekese and HS is well discussed above, hence presenting the crystal-clear evidence of potential enhancement of the final products with potent bioactive ingredients. According to the literature, different classes of food antioxidants (i.e., $\alpha$-tocopherol, ascorbic acid, carotenoids, amino acids, peptides, proteins, flavonoids, and other phenolic compounds) may contribute significantly to the physiological and dietary antioxidant requirements of the consumer, which complements the body's natural resistance to oxidative damage [170,171]. Additionally, it has been reported that methanolic extract of $V$. amygdalina at a concentration of $0.01,0.02,0.05$, and $0.1 \mathrm{mg} / \mathrm{mL}$ exhibited high AOA, with $75.9 \%, 93.9 \%, 97.1 \%$, and $99.3 \%$ of the DPPH radicals scavenged, respectively [139]. Therefore, it could supplement the wort and final pito with antioxidant compounds, such as proanthocyanidine, phenol, flavonoids, anthocyanin, and tannins. Antioxidants originating from malted and unmalted cereal grains as well as hops (in this case, V. amygdalina), are reported to not only confer bioactive and pro-health properties but also play a crucial role in the foam maintenance, physicochemical stability, and shelf life of pito [143,172]. Considering the AOA of all the materials that are utilized in brewing, the final pito would be overwhelmed with putative AOA. Nonetheless, the AOA of various products was found to be affected by heat treatment $[76,173]$, hence mashing and wort boiling would reduce the 
concentration of the compounds linked to AOA in the final pito, thus resulting in a highly flavoured beer with moderate AOA.

\section{Shelf Life of Bioactive Pito}

Pito is characterized by a limited shelf life (stability) due to the presence of yeast and lactic acid bacteria (LAB), hence it is utilized/sold within a few days [174,175]. The spoilage of pito is attributed to the continuous fermentation of pito by yeast and LAB in the suspension. In addition, autolysis of yeast results in the leaking of undesirable substances and off-flavours into pito, thus altering the flavour and aroma and, consequently, the drinkability of the product. Though LAB is generally considered as beneficial microorganisms in promoting good health (probiotic) in pito and other food products, their continuous growth (due to their fastidious nature) [176] in pito results in the synthesis of lactic acid, which lowers the $\mathrm{pH}$ of pito. Continuous acidification of pito by LAB results in a sour taste and the alteration of volatiles. Sanni and colleagues [175] reported $3.4 \times 10^{5}, 1.2 \times 10^{2}$, and $4.1 \times 10^{3}$ of LAB, acetic acid bacteria, and yeast in green pito, respectively. Their presence decreases the shelf life of pito.

Many researchers have proposed methods to improve the shelf life of pito. For instance, [177] proposed filtration of green pito followed by pasteurization $\left(60\right.$ to $70{ }^{\circ} \mathrm{C}$ for $15 \mathrm{~min}$ ) and the addition of sodium metabisulphite. The method was not $100 \%$ efficient; however, it helped to extend the shelf life to eight weeks. Nevertheless, the addition of chemicals could alter the aroma, mouth feel, and texture of pito and hence result in low patronage of the product. Pasteurisation could aid to stabilise pito to some extent. However, the chemical method is not ideal due to flavour alteration, toxicity, cost, and availability of these chemicals to local brewers. Djameh et al. [164] recently reported that brewing pito with pure culture (L. delbrueckii and S. cerevisiae) extended the shelf life up to 3 days compared to pito brewed with dembila. However, due to the rapid synthesis of lactic acid, the product became undrinkable after 5 days of production. The authors also found a positive correlation between the concentration of lactic acid and consumer preference of pito. Conclusively, the spoilage of pito on the account of over-sourness is perceived at a lactic acid level of $0.86(\%, w / v)$. Coupling pasteurization and phytogenic-based extracts (HS and TT) may address the limitations of the above method. Ayirezang and colleagues [159] found that pasteurization and/or the addition of Moringa oleifera leaf extract improved the shelf life of pito for an additional four weeks; however, sensory evaluation of the product revealed that consumers preferred untreated samples to treated ones. The biocidal activities of T. tetraptera and H. sabdariffa (Malvaceae) have been extensively reviewed, and the results have revealed promising and potent activities of the extracts against important microorganisms causing the spoilage of pito. Therefore, the addition of concentrated extracts after fermentation may inhibit the growth of microorganisms responsible for spoilage, thus preventing pito from becoming soured, and consequently extending the shelf life. Jabeur and colleagues reported that the amount/concentration of HS extract is essential to achieve a productive biocidal activity, especially when incorporating it in food products or beverages [92]. The application of these two essential plants to brew pito may extend the shelf life, provide bioactive ingredients to promote the health of consumers, and result in economic benefits for brewers (high profits). Moreover, $[43,178]$ proposed the addition of plant extracts to improve the stabilization (shelf life) of pito. However, they generalized the kind of plants employed but, in this paper, pondered on specific plants (prekese and HS) due to their potent bioactive/flavouring properties.

\section{Incidence of Heavy Metals in Pito Samples}

According to [179], heavy metals are environmental contaminants capable of altering the physiological function of humans if present in foods at high concentrations. Generally, the concentration of heavy metals in food products is associated with the material (steel, $\mathrm{Al}$, etc.) from which cooking utensils are made from, cooking process, storage, and type of sponge used to clean pots (i.e., wire scourer cleaning tool, kitchen nano emery magic clean, etc.) $[180,181]$. The degree leaching of heavy metals and their concentration in food was found to correlate with the type of cooking utensil [182]. 
Duodu et al. [40] reported that the concentration of $\mathrm{Ni}(0.040-0.176)$, lead $(\mathrm{Pb})(0.056-0.272)$, and cadmium (Cd) (0.011-0.048) in pito samples sourced across Ghana were above the respective maximum WHO guideline. The highest concentration of $\mathrm{Ni}(0.176 \mathrm{mg} / \mathrm{L})$ was detected in a sample sourced from Wa with the lowest, $0.040 \mathrm{mg} / \mathrm{L}$, from Tamale. Similarly, [183] found that the Al concentration in rice cooked in a traditional aluminium pot increased from $1.6 \pm 0.4$ (raw rice) to $18.1 \pm 1.4 \mathrm{mg} / \mathrm{g}$, compared to $1.7 \pm 0.3$ in rice cooked with a modern rice cooker. Interestingly, the presence of $\mathrm{Al}$ in raw rice could be associated with the soils where it was cultivated. In this regard, sorghum and other raw materials used in brewing pito could also be contaminated with heavy metals from the soil where they were cultivated. However, the risk of contamination from $\mathrm{Al}$ is further compounded since traditional brewers utilise pots made from aluminium in brewing pito coupled with repeated cleaning (scratching) with a steel wire scourer, consequently leaching these heavy metals into pito. These pots do not possess a protective coating, such as in modern cooking utensils.

Oz et al. [184] reported heavy metals (i.e., (chromium) $\mathrm{Cr}, \mathrm{Fe}, \mathrm{Ni}, \mathrm{Cu}, \mathrm{Zn}, \mathrm{Cd}$, (tin) $\mathrm{Sn}$, and $\mathrm{Pb}$ ) in beers $(n=25)$ sourced across Ankara, Turkey; the results were below the legislative limits. Similarly, all heavy metals detected in Ethiopian traditional fermented alcoholic beverages were below the safe limits set by the World Health Organization (WHO); nevertheless, the concentration of $\mathrm{Cd}$ and $\mathrm{Pb}$ in some samples was higher than the limit set by WHO [185]. Traditional brewers should be informed or educated about the wear of the pots they utilise for brewing and the need to change them periodically. Additionally, the type of sponge used to clean these pots is critical, hence it should be chosen carefully to avoid increasing the rate of leaching of heavy metals into pito. Preferably, they could use pots coated with an inert material though such pots might be comparably expensive and perhaps difficult to find in the local setting.

\section{Conclusions}

The potential application of Tetrapleura tetraptera and Hibiscus sabdariffa to brew highly flavoured and bioactive pito was demonstrated in this review accompanied with sufficient data from research works to buttress the novelty and feasibility. Most of the bioactive ingredients from prekese and HS have been proven to be promising in the prevention and treatment of diseases, mainly due to their antioxidant, hepatoprotective, immune-modulating, and antitumor activities. Experimental works have provided enough evidence backing the nutritional, phytochemical, and biological activities of prekese and HS, thus they may positively improve the health of consumers. Pito is widely consumed in Ghana, hence supplementing it with bioactive ingredients would serve as a vehicle to curb the numerous nutritional deficiencies that rural folks are battling. Moreover, the nutritional profile of pito has been extensively elucidated. The antioxidant and physiochemical parameters of the proposed beer may be high compared to traditional counterparts. Furthermore, the biocidal activities of prekese and HS could contribute to extending the shelf life of pito as it contains appreciable amounts of bioactive substances that can suppress $\mathrm{LAB}$, the predominant microorganism associated with pito spoilage. The new and enriched pito would be accepted by consumers since the materials utilised are well known by the local folks and generally considered as safe among them. The degree of leaching of heavy metals from brewing pots into pito depends on the material that it is made from and the type of sponge used in cleaning; hence, traditional brewers should carefully choose the pot utilised in brewing.

Author Contributions: P.A. and O.N.K. contributed to the ideas and organization of the content and wrote the manuscript. All authors have read and agreed to the published version of the manuscript.

Funding: This research received no external funding.

Acknowledgments: P.A. is grateful to the University of Otago for support via the University of Otago Doctoral Scholarship.

Conflicts of Interest: The authors declare no conflict of interest. 


\section{References}

1. Adadi, P.; Kovaleva, E.G.; Glukhareva, T.V.; Shatunova, S.A. Biotechnological production of non-traditional beer. AIP Conf. Proc. 2017, 1886, 1-13.

2. Demuyakor, B.; Ohta, Y. Characteristics of pito yeasts from Ghana. Food Microbiol. 1991, 8, 183-193. [CrossRef]

3. van der Aa Kühle, A.; Jesperen, L.; Glover, R.L.; Diawara, B.; Jakobsen, M. Identification and characterization of Saccharomyces cerevisiae strains isolated from West African sorghum beer. Yeast 2001, 18, 1069-1079. [CrossRef]

4. Kolawole, O.; Kayode, R.; Akinduyo, B. Proximate and microbial analyses of burukutu and pito produced in Ilorin, Nigeria. Afr. J. Biotechnol. 2007, 6, 587-590.

5. Lyumugabe, F.; Kamaliza, G.; Bajyana, E.; Thonart, P. Microbiological and physico-chemical characteristic of Rwandese traditional beer "Ikigage". Afr. J. Biotechnol. 2010, 9, 4241-4246.

6. Bansah, D. Traditional Brewing of Pito: Process and Product Characteristics. Master's Thesis, University of Ghana, Legon, Ghana, 1990.

7. Sefa-Dedeh, S.; Sanni, A.; Tetteh, G.; Sakyi-Dawson, E. Yeasts in the traditional brewing of pito in Ghana. World J. Microbiol. Biotechnol. 1999, 15, 593-597. [CrossRef]

8. Adesina, S.K.; Iwalewa, E.O.; Johnny, I.I. Tetrapleura tetraptera Taub-ethnopharmacology, chemistry, medicinal and nutritional values-a review. J. Pharm. Res. Int. 2016, 1-22. [CrossRef]

9. Adadi, P.; Barakova, N.V.; Muravyov, K.Y.; Krivoshapkina, E.F. Designing selenium functional foods and beverages: A review. Food Res. Int. 2019, 120, 708-725. [CrossRef]

10. Ojewole, J.A.; Adewunmi, C.O. Anti-inflammatory and hypoglycaemic effects of Tetrapleura tetraptera (Taub)[fabaceae] fruit aqueous extract in rats. J. Ethnopharmacol. 2004, 95, 177-182. [CrossRef]

11. Erukainure, O.L.; Ebuehi, O.A.; Adeboyejo, F.O.; Aliyu, M.; Elemo, G.N. Modulatory effect of fibre-enriched cake on alloxan-induced diabetic toxicity in rat brain tissues. Toxicol. Rep. 2014, 1, 445-449. [CrossRef]

12. Erukainure, O.L.; Onifade, O.F.; Odjobo, B.O.; Olasehinde, T.A.; Adesioye, T.A.; Tugbobo-Amisu, A.O.; Adenekan, S.O.; Okonrokwo, G.I. Ethanol extract of Tetrapleura tetraptera fruit peels: Chemical characterization, and antioxidant potentials against free radicals and lipid peroxidation in hepatic tissues. $J$. Taibah Univ. Sci. 2017, 11, 861-867. [CrossRef]

13. Igwe, O.; Akabuike, H. Free radical scavenging activity, phytochemistry and antimicrobial properties of Tetrapleura tetraptera Seeds. Int. Res. J. Chem. Chem. Sci. 2016, 3, 37-42.

14. Akintola, O.; Bodede, A.; Ogunbanjo, O. Nutritional and medicinal importance of Tetrapleura tetraptera fruits (Aridan). Afr. J. Sci. Res. 2015, 4, 33-38.

15. Ngassoum, M.; Jirovetz, L.; Buchbauer, G. SPME/GC/MS analysis of headspace aroma compounds of the Cameroonian fruit Tetrapleura tetraptera (Thonn.) Taub. Eur. Food Res. Technol. 2001, 213, 18-21. [CrossRef]

16. Udourioh, G.A.; Etokudoh, M.F. Essential oils and fatty acids composition of dry fruits of Tetrapleura tetraptera. J. Appl. Sci. Environ. Manag. 2014, 18, 419-424.

17. NATUPrekesedrink. Available online: https://www.facebook.com/natuprekesedrink/ (accessed on 11 February 2020).

18. Plotto, A.; Mazaud, F.; Röttger, A.; Steffel, K. Hibiscus: Post-Production Management for Improved Market Access; Food and Agriculture Organization of the UN (FAO): Rome, Italy, 2004.

19. Da-Costa-Rocha, I.; Bonnlaender, B.; Sievers, H.; Pischel, I.; Heinrich, M. Hibiscus sabdariffa L.-A phytochemical and pharmacological review. Food Chem. 2014, 165, 424-443. [CrossRef]

20. Morton, J.F.; Dowling, C.F. Fruits of Warm Climates; Creative Resources Systems: Miami, FL, USA, 1987; Volume 20534.

21. Ross, I.A. Hibiscus sabdariffa. In Medicinal Plants of the World; Springer: Berlin/Heidelberg, Germany, 2003; pp. 267-275.

22. Bako, I.; Mabrouk, M.; Abubakar, A. Antioxidant effect of ethanolic seed extract of Hibiscus sabdariffa linn (Malvaceae) alleviate the toxicity induced by chronic administration of sodium nitrate on some haematological parameters in wistars rats. Adv. J. Food Sci. Technol. 2009, 1, 39-42.

23. Bolade, M.; Oluwalana, I.; Ojo, O. Commercial practice of roselle (Hibiscus sabdariffa L.) beverage production: Optimization of hot water extraction and sweetness level. World J. Agric. Sci. 2009, 5, 126-131.

24. Ismail, A.; Ikram, E.H.K.; Nazri, H.S.M. Roselle (Hibiscus sabdariffa L.) seeds-nutritional composition, protein quality and health benefits. Food 2008, 2, 1-16. 
25. Okoro, C.E. Production of red wine from roselle (Hibiscus sabdariffa) and pawpaw (Carica papaya) using palm-wine yeast (Saccharomyces cerevisiae). Niger. Food J. 2007, 25, 158-164. [CrossRef]

26. Rao, P.U. Nutrient composition and biological evaluation of mesta (Hibiscus sabdariffa) seeds. Plant Foods Hum. Nutr. 1996, 49, 27-34. [PubMed]

27. Tsai, P.-J.; McIntosh, J.; Pearce, P.; Camden, B.; Jordan, B.R. Anthocyanin and antioxidant capacity in Roselle (Hibiscus sabdariffa L.) extract. Food Res. Int. 2002, 35, 351-356. [CrossRef]

28. Nwahia, C.R.; Opara, C.C. Production of wine from zobo (Hibiscus sabdariffa) flower juice. J. Biochem. Technol. 2012, 3, 436-437.

29. Alobo, A.P.; Offonry, S. Characteristics of coloured wine produced from roselle (Hibiscus sabdariffa) calyx extract. J. Inst. Brew. 2009, 115, 91-94. [CrossRef]

30. Ali, S.A.E.; Mohamed, A.H.; Mohammed, G.E.E. Fatty acid composition, anti-inflammatory and analgesic activities of Hibiscus sabdariffa Linn. seeds. J. Adv. Vet. Anim. Res. 2014, 1, 50-57. [CrossRef]

31. Eggensperger, H.; Wilker, M. Hibiscus-Extrakt: Ein hautverträglicher Wirkstoffkomplex aus AHA's und polysacchariden. Teil 1. Parfümerie Und Kosmet. 1996, 77, 522-523.

32. Amaya-Cruz, D.; Peréz-Ramírez, I.F.; Pérez-Jiménez, J.; Nava, G.M.; Reynoso-Camacho, R. Comparison of the bioactive potential of Roselle (Hibiscus sabdariffa L.) calyx and its by-product: Phenolic characterization by UPLC-QTOF MSE and their anti-obesity effect in vivo. Food Res. Int. 2019, 126, 108589. [CrossRef]

33. Ali, B.H.; Wabel, N.A.; Blunden, G. Phytochemical, pharmacological and toxicological aspects of Hibiscus sabdariffa L.: A review. Phytother. Res. Int. J. Devoted Pharmacol. Toxicol. Eval. Nat. Prod. Deriv. 2005, 19, 369-375.

34. Adadi, P.; Barakova, N.V.; Krivoshapkina, E.F. Scientific approaches to improving artisan methods of producing local food condiments in Ghana. Food Control 2019. [CrossRef]

35. Adadi, P.; Kovaleva, E.; Glukhareva, T.; Shatunova, S.; Petrov, A. Production and analysis of non-traditional beer supplemented with sea buckthorn. Agron. Res. 2017, 15, 1831-1845.

36. Ducruet, J.; Rébénaque, P.; Diserens, S.; Kosińska-Cagnazzo, A.; Héritier, I.; Andlauer, W. Amber ale beer enriched with goji berries-The effect on bioactive compound content and sensorial properties. Food Chem. 2017, 226, 109-118. [CrossRef] [PubMed]

37. Kawa-Rygielska, J.; Adamenko, K.; Kucharska, A.Z.; Prorok, P.; Piórecki, N. Physicochemical and antioxidative properties of Cornelian cherry beer. Food Chem. 2019, 281, 147-153. [CrossRef] [PubMed]

38. Adazabra, A.N.; Ntiforo, A.; Bamford, S.A. Analysis of essential elements in P ito-A cereal food drink and its brands by the single-comparator method of neutron activation analysis. Food Sci. Nutr. 2014, 2, 230-235. [CrossRef] [PubMed]

39. Egemba, K.; Etuk, V.E. A kinetic study of burukutu fermentation. J. Eng. Appl. Sci. 2007, 2, 1193-1198.

40. Ezeonu, C.S.; Nwokwu, C.D.U.; Kadiri, B. Comparative physico-chemical analysis of locally brewed beer (Burukutu) from corn, millet and sorghum. Am. J. Sci. Technol. 2017, 3, 43-48.

41. Kumar, A.; Nair, A.; Reddy, A.; Garg, A. Analysis of essential elements in Pragya-peya-A herbal drink and its constituents by neutron activation. J. Pharm. Biomed. Anal. 2005, 37, 631-638. [CrossRef]

42. Duodu, G.O.; Amartey, E.O.; Asumadu-Sakyi, A.B.; Adjei, C.A.; Quashie, F.K.; Nsiah-Akoto, I.; Ayanu, G. Mineral profile of pito from Accra, Tamale, Bolgatanga and Wa in Ghana. Food Public Health 2012, 2, 1-5. [CrossRef]

43. Konfo, C.T.R.; Chabi, N.W.; Dahouenon-Ahoussi, E.; Cakpo-Chichi, M.; Soumanou, M.M.; Sohounhloue, D.C.K. Improvement of African traditional sorghum beers quality and potential applications of plants extracts for their stabilization: A review. J. Microbiol. Biotechnol. Food Sci. 2015, 5, 190. [CrossRef]

44. Ajiboye, T.O.; Iliasu, G.A.; Adeleye, A.O.; Abdussalam, F.A.; Akinpelu, S.A.; Ogunbode, S.M.; Jimoh, S.O.; Oloyede, O.B. Nutritional and antioxidant dispositions of sorghum/millet-based beverages indigenous to Nigeria. Food Sci. Nutr. 2014, 2, 597-604. [CrossRef]

45. Chevassus-Agnes, S.; Favier, J.; Joseph, A. Traditional technology and nutritive value of Cameroon sorghum beers. Cah. Onarest 1979, 2, 83-112.

46. Nout, M. Composition of foods-African traditional beers. Food Lab. Newsl. 1987, 8, 18-20.

47. Akin-Idowu, P.E.; Ibitoye, D.O.; Ademoyegun, O.T.; Adeniyi, O.T. Chemical composition of the dry fruit of Tetrapleura tetraptera and its potential impact on human health. J. Herbsspices Med. Plants 2011, 17, 52-61. [CrossRef] 
48. Abugri, D.A.; Pritchett, G. Determination of chlorophylls, carotenoids, and fatty acid profiles of Tetrapleura tetraptera seeds and their health implication. J. Herbsspices Med. Plants 2013, 19, 391-400. [CrossRef]

49. Oguoma, O.; Ezeifeka, G.; Adeleye, S.; Oranusi, S.; Amadi, E. Antimicrobial activity, proximate and amino acids analysis of Tetrapleura Tetraptera. Niger. J. Microbiol. 2015, 27, 2709-2718.

50. Leitzmann, C. Characteristics and health benefits of phytochemicals. Complementary Med. Res. 2016, 23, 69-74. [CrossRef]

51. Godfrey, N.E. Proximate and phytochemical composition of the pulp of Tetrapleura tetraptera fruits consumed in Abakaliki, Nigeria. Int. J. Eng. Res. Technol. (Ijert) 2015, 4, 1286-1294.

52. Irondi, E.A.; Oboh, G.; Agboola, S.O.; Boligon, A.A.; Athayde, M.L. Phenolics extract of Tetrapleura tetraptera fruit inhibits xanthine oxidase and Fe2+-induced lipid peroxidation in the kidney, liver, and lungs tissues of rats in vitro. Food Sci. Hum. Wellness 2016, 5, 17-23. [CrossRef]

53. Irondi, A.; Anokam, K.; Chukwuma, P. Phenological variation in the in-vitro antioxidant properties and alpha-amylase inhibitory activity of Tetrapleura tetraptera Pod. Int. J. Pharm. Sci. Drug Res. 2013, 5, 108-112.

54. Chung, K.-T.; Wong, T.Y.; Wei, C.-I.; Huang, Y.-W.; Lin, Y. Tannins and human health: A review. Crit. Rev. Food Sci. Nutr. 1998, 38, 421-464. [CrossRef]

55. Ashok, P.K.; Upadhyaya, K. Tannins are astringent. J. Pharmacogn. Phytochem. 2012, 1, 45-50.

56. Igwe, O.U.; Okwu, D.E. Phytochemical composition and anti-inflammatory activities of Brachystegia eurycoma seeds and stem bark. Der Pharma Chem. 2013, 5, 224-228.

57. Enujiugha, V.; Agbede, J. Nutritional and anti-nutritional characteristics of African oil bean (Pentaclethra macrophylla Benth) seeds. Appl. Trop. Agric. 2000, 5, 11-14.

58. Mahmoud, M.H.; Abou-Arab, A.A.; Abu-Salem, F.M.; Aymerich, T.; Picouet, P.; Monfort, J.; Decker, E.; Chan, W.; Livisay, S.; Butterfield, D. Biochemistry, Practical/Research Method: A Fundamental Approach. Am. J. Food Technol. 2008, 12, 114-129.

59. Rakić, S.; Maletić, R.O.; Perunović, M.N.; Svrzić, G. Influence of thermal treatment on tannin content and antioxidation effect of oak acorn Quercus cerris extract. J. Agric. Sci. Belgrade 2004, 49, 97-107. [CrossRef]

60. Rausch, W.-D.; Liu, S.; Gille, G.; Radad, K. Neuroprotective effects of ginsenosides. Acta Neurobiol Exp (Wars) 2006, 66, 369-375. [PubMed]

61. Sodipo, O.; Akinniyi, J.A.; Ogunbameru, J. Studies on certain characteristics of extracts of bark of Pausinystalia johimbe and Pausinystalia macroceras (K Schum) Pierre ex Beille. Glob. J. Pure Appl. Sci. 2000, 6, 83-88. [CrossRef]

62. Okolie, N.P.; Falodun, A.; Davids, O. Evaluation of the antioxidant activity of root extract of pepper fruit (Dennetia tripetala), and it's potential for the inhibition of lipid peroxidation. Afr. J. Tradit. Complementary Altern. Med. 2014, 11, 221-227. [CrossRef]

63. Ghasemi, K.; Ghasemi, Y.; Ebrahimzadeh, M.A. Antioxidant activity, phenol and flavonoid contents of 13 citrus species peels and tissues. Pak. J. Pharm. Sci. 2009, 22, 277-281.

64. Özçelik, B.; Kartal, M.; Orhan, I. Cytotoxicity, antiviral and antimicrobial activities of alkaloids, flavonoids, and phenolic acids. Pharm. Biol. 2011, 49, 396-402. [CrossRef]

65. Amadi, S.W.; Zhang, Y.; Wu, G. Research progress in phytochemistry and biology of Aframomum species. Pharm. Biol. 2016, 54, 2761-2770. [CrossRef]

66. Fecchio, D.; Sirois, P.; Russo, M.; Jancar, S. Studies on inflammatory response induced by Ehrlich tumor in mice peritoneal cavity. Inflammation 1990, 14, 125-132. [CrossRef] [PubMed]

67. Ozaslan, M.; Karagoz, I.; Lawal, R.; Kilic, I.; Cakir, A.; Odesanmi, O.; Guler, I.; Ebuehi, O. Cytotoxic and anti-proliferative activities of the Tetrapleura tetraptera fruit extract on ehrlich ascites tumor cells. Int. J. Pharmacol. 2016, 12, 655-662. [CrossRef]

68. Atawodi, S.E.-O.; Yakubu, O.E.; Liman, M.L.; Iliemene, D.U. Effect of methanolic extract of Tetrapleura tetraptera (Schum and Thonn) Taub leaves on hyperglycemia and indices of diabetic complications in alloxan-induced diabetic rats. Asian Pac. J. Trop. Biomed. 2014, 4, 272-278. [CrossRef]

69. Onda, E.; Sonibare, M.; Ajayi, A.; Umukoro, S. Anti-inflammatory and Antioxidant Effects of Tetrapleura tetraptera (Schumach \& Thonn.) Taub. Fruit Extract in Carrageenan/Kaolin-induced Acute Monoarthritis in Rats. Niger. J. Pharm. Res. 2018, 13, 157-166.

70. Komlaga, G. Isolation and characterisation of the chemical constituents and the hypoglycaemic potentials of the fruit of Tetrapleura Tetraptera T.(Mimosaceae). Masters's Thesis, Kwame Nkrumah University of Science and Technology, Kumasi, Ghana, 2004. 
71. Kuate, D.; Kengne, A.P.N.; Biapa, C.P.N.; Azantsa, B.G.K.; Muda, W.A.M.B.W. Tetrapleura tetraptera spice attenuates high-carbohydrate, high-fat diet-induced obese and type 2 diabetic rats with metabolic syndrome features. Lipids Health Dis. 2015, 14, 50. [CrossRef]

72. Famobuwa, O.; Lajide, L.; Owolabi, B.; Osho, I.; Amuho, U. Antioxidant activity of the fruit and stem bark of Tetrapleura tetraptera Taub (Mimosaceae). J. Pharm. Res. Int. 2016, 1-4. [CrossRef]

73. Joel, J.; Sheena, O.; Martins, O.; Onyemauche, N.; Emmanuel, A. Comparative antioxidant capacity of aqueous and ethanol fruit extracts of Tetrapleura tetraptera. J. Biol. Sci. 2017, 17, 185-193. [CrossRef]

74. Moukette, B.M.; Pieme, A.C.; Biapa, P.C.N.; Njimou, J.R.; Stoller, M.; Bravi, M.; Yonkeu Ngogang, J. In vitro ion chelating, antioxidative mechanism of extracts from fruits and barks of Tetrapleura tetraptera and their protective effects against fenton mediated toxicity of metal ions on liver homogenates. Evid. -Based Complementary Altern. Med. 2015, 14. [CrossRef]

75. Badu, M.; Mensah, J.K.; Boadi, N.O. Antioxidant activity of methanol and ethanol/water extracts of Tetrapleura tetraptera and Parkia biglobosa. Int. J. Pharm. Biol. Sci. 2012, 3, 312-321.

76. Nwaichi, E.; Anyanwu, P. Effect of heat treatment on the antioxidant properties of Tetrapleura tetraptera, Xylopia aethiopica and Piper guineense. Int. J. Biotechnol. Food Sci. 2013, 1, 1-5.

77. Sonibare, M.A.; EE, E.E.O.; Ajayi, A.M.; Umukoro, S. In vitro antioxidant and membrane stabilization activities of fruit extract and fractions of Tetrapleura tetraptera (Schumach \& Thonn.) Taub. J. Pharm. Bioresour. 2015, 12, 95-105.

78. Nwidu, L.L.; Alikwe, P.C.N.; Elmorsy, E.; Carter, W.G. An investigation of potential sources of nutraceuticals from the Niger Delta areas, Nigeria for attenuating oxidative stress. Medicines 2019, 6, 15. [CrossRef] [PubMed]

79. Gberikon, G.; Adeoti, I.; Aondoackaa, A. Effect of ethanol and aqueous solutions as extraction solvents on phytochemical screening and antibacterial activity of fruit and stem bark extracts of Tetrapleura tetrapteraon Streptococcus salivarus and Streptococcus mutans. Int. J. Curr. Microbiol. Appl. Sci. 2015, 4, 404-410.

80. Achi, O. Composition and antibacterial activities of Tetrapleura tetraptera Taub. pod extracts. Res. J. Microbiol. 2010, 5, 1138-1144.

81. Noamesi, B.K.; Mensah, J.F.; Bogale, M.; Dagne, E.; Adotey, J. Antiulcerative properties and acute toxicity profile of some African medicinal plant extracts. J. Ethnopharmacol. 1994, 42, 13-18. [CrossRef]

82. Aladesanmi, A.J. Tetrapleura tetraptera: Molluscicidal activity and chemical constituents. Afr. J. Tradit. Complementary Altern. Med. 2007, 4, 23-36. [CrossRef]

83. Odesanmi, S.; Lawal, R.; Ojokuku, S. Effects of ethanolic extract of Tetrapleura tetraptera on liver function profile and histopathology in male Dutch white rabbits. Int. J. Trop. Med. 2009, 4, 136-139.

84. Effiong, G.; Udoh, I.; Essien, G.; Ajibola, D.; Archibong, K. Effect of aqueous extract of Tetrapleura tetraptera on excision wounds in albino rats. Int. Res. J. Plant Sci. 2014, 5, 57-60.

85. Juhari, N.H.; Petersen, M.A. Physicochemical Properties and Oxidative Storage Stability of Milled Roselle (Hibiscus sabdariffa L.) Seeds. Molecules 2018, 23, 385. [CrossRef]

86. Salah, E.M.; Hayat, Z.E. Proximate composition of Karkadeh (Hibiscus sabdariffa) seeds and some functional properties of seed protein isolate as influenced by $\mathrm{pH}$ and $\mathrm{NaCl}$. Int. J. Food Sci. Nutr. 2009, 60, 183-194. [CrossRef]

87. Ayodeji, P.; Onoja, U.; Olanrewaju, O.; Aniebiet, T. Effects of Sorghum bicolor, Carica papaya and Hibiscus sabdariffa leaves extracts on some haematological indices of cyclophosphamide-induced anaemic albino rats. Niger. J. Nutr. Sci. 2019, 40, 142-151.

88. Adanlawo, I.; Ajibade, V. Nutritive value of the two varieties of roselle (Hibiscus sabdariffa) calyces soaked with wood ash. Pak. J. Nutr. 2006, 5, 555-557.

89. Nnam, N.; Onyeke, N. Chemical composition of two varieties of sorrel (Hibiscus sabdariffa L.), calyces and the drinks made from them. Plant Foods Hum. Nutr. 2003, 58, 1-7. [CrossRef]

90. Kubuga, C.K.; Hong, H.G.; Song, W.O. Hibiscus sabdariffa meal improves iron status of childbearing age women and prevents stunting in their toddlers in Northern Ghana. Nutrients 2019, 11, 198. [CrossRef] [PubMed]

91. Nguyen, T.-T.; Phan-Thi, H.; Pham-Hoang, B.-N.; Ho, P.-T.; Tran, T.T.T.; Waché, Y. Encapsulation of Hibiscus sabdariffa L. anthocyanins as natural colours in yeast. Food Res. Int. 2018, 107, 275-280. [CrossRef] [PubMed] 
92. Jabeur, I.; Pereira, E.; Barros, L.; Calhelha, R.C.; Soković, M.; Oliveira, M.B.P.; Ferreira, I.C. Hibiscus sabdariffa L. as a source of nutrients, bioactive compounds and colouring agents. Food Res. Int. 2017, 100, 717-723. [CrossRef]

93. Mckay, D. Can hibiscus tea lower blood pressure. Agro Food Ind. Hi-Tech 2009, 20, 40-42.

94. Baxter, K.; Driver, S.; Williamson, E. Stockley's Herbal Medicines Interactions; Pharmaceutical Press: London, UK, 2013.

95. Salah, A.; Gathumbi, J.; Vierling, W. Inhibition of intestinal motility by methanol extracts of Hibiscus sabdariffa L.(Malvaceae) in rats. Phytother. Res. 2002, 16, 283-285. [CrossRef]

96. Alarcón-Alonso, J.; Zamilpa, A.; Aguilar, F.A.; Herrera-Ruiz, M.; Tortoriello, J.; Jimenez-Ferrer, E. Pharmacological characterization of the diuretic effect of Hibiscus sabdariffa Linn (Malvaceae) extract. J. Ethnopharmacol. 2012, 139, 751-756. [CrossRef]

97. Maganha, E.G.; da Costa Halmenschlager, R.; Rosa, R.M.; Henriques, J.A.P.; de Paula Ramos, A.L.L.; Saffi, J. Pharmacological evidences for the extracts and secondary metabolites from plants of the genus Hibiscus. Food Chem. 2010, 118, 1-10. [CrossRef]

98. Fernández-Arroyo, S.; Rodríguez-Medina, I.C.; Beltrán-Debón, R.; Pasini, F.; Joven, J.; Micol, V.; Segura-Carretero, A.; Fernández-Gutiérrez, A. Quantification of the polyphenolic fraction and in vitro antioxidant and in vivo anti-hyperlipemic activities of Hibiscus sabdariffa aqueous extract. Food Res. Int. 2011, 44, 1490-1495. [CrossRef]

99. Borrás-Linares, I.; Herranz-López, M.; Barrajón-Catalán, E.; Arráez-Román, D.; Gonzálezlvarez, I.; Bermejo, M.; Gutiérrez, A.F.; Micol, V.; Segura-Carretero, A. Permeability study of polyphenols derived from a phenolic-enriched Hibiscus sabdariffa extract by UHPLC-ESI-UHR-Qq-TOF-MS. Int. J. Mol. Sci. 2015, 16, 18396-18411. [CrossRef] [PubMed]

100. Meraiyebu, A.; Olaniyan, O.; Eneze, C.; Anjorin, Y.; Dare, J. Anti-inflammatory activity of methanolic extract of Hibiscus sabdariffa on carrageenan induced inflammation in wistar rat. Int. J. Pharm. Sci. Invent. 2013, 2, $22-24$.

101. Obouayeba, A.P.; Meité, S.; Boyvin, L.; Yeo, D.; Kouakou, T.H.; N’Guessan, J.D. Cardioprotective and anti-inflammatory activities of a polyphenols enriched extract of Hibiscus sabdariffa petal extracts in wistar rats. J. Pharmacogn. Phytochem. 2015, 4, 57-63.

102. Jabeur, I.; Pereira, E.; Caleja, C.; Calhelha, R.C.; Soković, M.; Catarino, L.; Barros, L.; Ferreira, I.C. Exploring the chemical and bioactive properties of Hibiscus sabdariffa L. calyces from Guinea-Bissau (West Africa). Food Funct. 2019, 10, 2234-2243. [CrossRef]

103. Dafallah, A.A.; Al-Mustafa, Z. Investigation of the anti-inflammatory activity of Acacia nilotica and Hibiscus sabdariffa. Am. J. Chin. Med. 1996, 24, 263-269. [CrossRef]

104. Nguyen, N.; Le, H.; Pham, D.; Tran, T. Evaluation of physical, nutritional and sensorial properties cookie supplied with Hibiscus sabdariffa L. seed powder (without shell). Int. Food Res. J. 2018, 25, 1281-1287.

105. Tseng, T.-H.; Wang, C.-J.; Kao, E.-S. Hibiscus protocatechuic acid protects against oxidative damage induced by tert-butylhydroperoxide in rat primary hepatocytes. Chem. -Biol. Interact. 1996, 101, 137-148. [CrossRef]

106. Aganbi, E.; Onyeukwu, B.; Avwioroko, J.; Tonukari, J. Effect of fermentation on sensory, nutritional and antioxidant properties of mixtures of aqueous extracts of Hibiscus sabdariffa (zobo) and Raphia hookeri (raffia) wine. Niger. J. Sci. Environ. 2017, 15, 66-74.

107. Usoh, I.; Akpan, E.; Etim, E.; Farombi, E. Antioxidant actions of dried flower extracts of Hibiscus sabdariffa L. on sodium arsenite-induced oxidative stress in rats. Pak. J. Nutr. 2005, 4, 135-141.

108. Farombi, E.O.; Fakoya, A. Free radical scavenging and antigenotoxic activities of natural phenolic compounds in dried flowers of Hibiscus sabdariffa L. Mol. Nutr. Food Res. 2005, 49, 1120-1128. [CrossRef] [PubMed]

109. Farombi, E.; Ige, O. Hypolipidemic and antioxidant effects of ethanolic extract from dried calyx of Hibiscus sabdariffa in alloxan-induced diabetic rats. Fundam. Clin. Pharmacol. 2007, 21, 601-609. [CrossRef] [PubMed]

110. Duh, P.-D.; Yen, G.-C. Antioxidative activity of three herbal water extracts. Food Chem. 1997, 60, 639-645. [CrossRef]

111. Mohd-Esa, N.; Hern, F.S.; Ismail, A.; Yee, C.L. Antioxidant activity in different parts of roselle (Hibiscus sabdariffa L.) extracts and potential exploitation of the seeds. Food Chem. 2010, 122, 1055-1060. [CrossRef]

112. Mossalam, H.H.; Abd-El Aty, O.A.; Morgan, E.N.; Youssaf, S.; Mackawy, A.M.H. Biochemical and ultra structure studies of the antioxidant effect of aqueous extract of hibiscus sabdariffa on the nephrotoxicity induced by organophosphorous pesticide (malathion) on the adult albino rats. J. Am. Sci. 2011, 7, 561-572. 
113. Olaleye, M.T.; Rocha, B.J. Acetaminophen-induced liver damage in mice: Effects of some medicinal plants on the oxidative defense system. Exp. Toxicol. Pathol. 2008, 59, 319-327. [CrossRef] [PubMed]

114. Rosemary, R.; Haro, G. Antidiabetic effect of roselle calyces extract (Hibiscus sabdariffa L.) in streptozotocin induced mice. Int. J. Pharmtech Res. 2014, 6, 1703-1711.

115. Sachdewa, A.; Khemani, L. Effect of Hibiscus rosa sinensis Linn. ethanol flower extract on blood glucose and lipid profile in streptozotocin induced diabetes in rats. J. Ethnopharmacol. 2003, 89, 61-66. [CrossRef]

116. Sachdewa, A.; Nigam, R.; Khemani, L. Hypoglycemic effect of Hibiscus rosa sinensis L. leaf extract in glucose and streptozotocin induced hyperglycemic rats. Indian J. Exp. Biol. 2001, 39, 284-286.

117. Mozaffari-Khosravi, H.; Jalali-Khanabadi, B.; Afkhami-Ardekani, M.; Fatehi, F.; Noori-Shadkam, M. The effects of sour tea (Hibiscus sabdariffa) on hypertension in patients with type II diabetes. J. Hum. Hypertens. 2009, 23, 48-54. [CrossRef]

118. McKay, D.L.; Chen, C.O.; Saltzman, E.; Blumberg, J.B. Hibiscus sabdariffa L. tea (tisane) lowers blood pressure in prehypertensive and mildly hypertensive adults. J. Nutr. 2010, 140, 298-303. [CrossRef] [PubMed]

119. Obiefuna, P.; Owolabi, O.; Adegunloye, B.; Obiefuna, I.; Sofola, O. The petal extract of Hibiscus sabdariffa produces relaxation of isolated rat aorta. Int. J. Pharmacogn. 1994, 32, 69-74. [CrossRef]

120. Ojeda, D.; Jiménez-Ferrer, E.; Zamilpa, A.; Herrera-Arellano, A.; Tortoriello, J.; Alvarez, L. Inhibition of angiotensin convertin enzyme (ACE) activity by the anthocyanins delphinidin-and cyanidin-3-O-sambubiosides from Hibiscus sabdariffa. J. Ethnopharmacol. 2010, 127, 7-10. [CrossRef]

121. Mojiminiyi, F.; Adegunloye, B.; Egbeniyi, Y.; Okolo, R. An investigation of the diuretic effect of an aqueous extract of the petals of Hibiscus sabdariffa. J. Med. Med. Sci. 2000, 2, 77-80.

122. Inuwa, I.; Ali, B.H.; Al-Lawati, I.; Beegam, S.; Ziada, A.; Blunden, G. Long-term ingestion of Hibiscus sabdariffa calyx extract enhances myocardial capillarization in the spontaneously hypertensive rat. Exp. Biol. Med. 2012, 237, 563-569. [CrossRef]

123. Adegunloye, B.; Omoniyi, J.; Owolabi, O.; Ajagbonna, O.; Sofola, O.; Coker, H. Mechanisms of the blood pressure lowering effect of the calyx extract of Hibiscus sabdariffa in rats. Afr. J. Med. Med Sci. 1996, 25, 235-238.

124. Ajay, M.; Chai, H.; Mustafa, A.; Gilani, A.H.; Mustafa, M.R. Mechanisms of the anti-hypertensive effect of Hibiscus sabdariffa L. calyces. J. Ethnopharmacol. 2007, 109, 388-393. [CrossRef]

125. Huang, C.-N.; Chan, K.-C.; Lin, W.-T.; Su, S.-L.; Wang, C.-J.; Peng, C.-H. Hibiscus sabdariffa inhibits vascular smooth muscle cell proliferation and migration induced by high glucose-A mechanism involves connective tissue growth factor signals. J. Agric. Food Chem. 2009, 57, 3073-3079. [CrossRef]

126. Puro, K.-U.; Aochen, C.; Ghatak, S.; Das, S.; Sanjukta, R.; Mahapatra, K.P.; Jha, A.K.; Shakuntala, I.; Sen, A. Studies on the therapeutic properties of Roselle (Hibiscus sabdariffa) calyx: A popular ingredient in the cuisine of North East India. Int. J. Food Sci. Nutr. 2017, 2, 01-06.

127. Fullerton, M.; Khatiwada, J.; Johnson, J.U.; Davis, S.; Williams, L.L. Determination of antimicrobial activity of sorrel (Hibiscus sabdariffa) on Esherichia coli O157: H7 isolated from food, veterinary, and clinical samples. J. Med. Food 2011, 14, 950-956. [CrossRef]

128. Fakeye, T.O.; Pal, A.; Bawankule, D.; Yadav, N.; Khanuja, S. Toxic effects of oral administration of extracts of dried calyx of Hibiscus sabdariffa L. (Malvaceae). Phytother. Res. Int. J. Devoted Pharmacol. Toxicol. Eval. Nat. Prod. Deriv. 2009, 23, 412-416.

129. Abubakar, M.; Lawal, A.; Suleiman, B.; Abdullahi, K. Hepatorenal toxicity studies of sub-chronic administration of calyx aqueous extracts of Hibiscus sabdariffa in albino rats. Bayero J. Pure Appl. Sci. 2010, 3, 16-19. [CrossRef]

130. Sireeratawong, S.; Itharat, A.; Khonsung, P.; Lertprasertsuke, N.; Jaijoy, K. Toxicity studies of the water extract from the calyces of Hibiscus sabdariffa L. in rats. Afr. J. Tradit. Complementary Altern. Med. 2013, 10, 122-127. [CrossRef]

131. Onyenekwe, P.; Ajani, E.; Ameh, D.; Gamaniel, K. Antihypertensive effect of roselle (Hibiscus sabdariffa) calyx infusion in spontaneously hypertensive rats and a comparison of its toxicity with that in Wistar rats. Cell Biochem. Funct. 1999, 17, 199-206. [CrossRef]

132. Gaya, I.; Mohammad, O.; Suleiman, A.; Maje, M.; Adekunle, A. Toxicological and lactogenic studies on the seeds of Hibiscus sabdariffa Linn (Malvaceae) extract on serum prolactin levels of albino wistar rats. Internet J. Endocrinol. 2009, 5, 1-6. 
133. Akindahunsi, A.; Olaleye, M. Toxicological investigation of aqueous-methanolic extract of the calyces of Hibiscus sabdariffa L. J. Ethnopharmacol. 2003, 89, 161-164. [CrossRef]

134. Adadi, P.; Kovaleva, E.; Glukhareva, T.; Barakova, N. Production and investigations of antioxidant rich beverage: Utilizing Monascus purpureus IHEM LY2014-0696 and various malts. Agron. Res 2018, 16, 1312-1321.

135. Nsengumuremyi, D.; Adadi, P.; Ukolova, M.V.; Barakova, N.V. Effects of ultradisperse humic sapropel suspension on microbial growth and fermentation parameters of barley dstillate. Fermentation 2019, 5, 24. [CrossRef]

136. Sore, A. ALBERT SORE'S MEMOIR-Pito: Nothern Ghana's Traditional Brew. Available online: https://www. a1radioonline.com/6494/albert-sores-memoir-pito-nothern-ghanas-traditional-brew/index.html (accessed on 11 February 2020).

137. Lyumugabe, F.; Uyisenga, J.P.; Songa, E.B.; Thonart, P. Production of traditional sorghum beer "Ikigage" using Saccharomyces cerevisae, Lactobacillus fermentum and Issatckenkia orientalis as starter cultures. Food Nutr. Sci. 2014, 6, 507-515.

138. Mbatchou, V.C.; Nabayire, K.O.; Akuoko, Y. Vernonia amygdalina Leaf: Unveiling its antacid and carminative properties In Vitro. Curr. Sci. 2017, 3, 148-155.

139. Erasto, P.; Grierson, D.S.; Afolayan, A.J. Evaluation of antioxidant activity and the fatty acid profile of the leaves of Vernonia amygdalina growing in South Africa. Food Chem. 2007, 104, 636-642. [CrossRef]

140. Erasto, P.; Grierson, D.; Afolayan, A. Antioxidant constituents in Vernonia amygdalina. Leaves. Pharm. Biol. 2007, 45, 195-199. [CrossRef]

141. Habtamu, A.; Melaku, Y. Antibacterial and antioxidant compounds from the flower extracts of Vernonia amygdalina. Adv. Pharmacol. Sci. 2018, 6. [CrossRef]

142. Alara, O.R.; Abdurahman, N.H.; Ukaegbu, C.I.; Kabbashi, N.A. Extraction and characterization of bioactive compounds in Vernonia amygdalina leaf ethanolic extract comparing Soxhlet and microwave-assisted extraction techniques. J. Taibah Univ. Sci. 2019, 13, 414-422. [CrossRef]

143. Fumi, M.D.; Galli, R.; Lambri, M.; Donadini, G.; De Faveri, D.M. Effect of full-scale brewing process on polyphenols in Italian all-malt and maize adjunct lager beers. J. Food Compos. Anal. 2011, 24, 568-573. [CrossRef]

144. Zhao, H. Effects of processing stages on the profile of phenolic compounds in beer. In Processing and Impact on Active Components in Food; Elsevier: Amsterdam, The Netherlands, 2015; pp. 533-539.

145. Pascoe, H.M.; Ames, J.M.; Chandra, S. Critical stages of the brewing process for changes in antioxidant activity and levels of phenolic compounds in ale. J. Am. Soc. Brew. Chem. 2003, 61, 203-209. [CrossRef]

146. Koren, D.; Kun, S.; Vecseri, B.H.; Kun-Farkas, G. Study of antioxidant activity during the malting and brewing process. J. Food Sci. Technol. 2019, 56, 3801-3809. [CrossRef]

147. Szwajgier, D. Content of individual phenolic acids in worts and beers and their possible contribution to the antiradical activity of beer. J. Inst. Brew. 2009, 115, 243-252. [CrossRef]

148. Limón, R.I.; Peñas, E.; Torino, M.I.; Martínez-Villaluenga, C.; Dueñas, M.; Frias, J. Fermentation enhances the content of bioactive compounds in kidney bean extracts. Food Chem. 2015, 172, 343-352. [CrossRef]

149. Villarreal-Soto, S.A.; Beaufort, S.; Bouajila, J.; Souchard, J.-P.; Renard, T.; Rollan, S.; Taillandier, P. Impact of fermentation conditions on the production of bioactive compounds with anticancer, anti-inflammatory and antioxidant properties in kombucha tea extracts. Process Biochem. 2019, 83, 44-54. [CrossRef]

150. Verni, M.; Verardo, V.; Rizzello, C.G. How fermentation affects the antioxidant properties of cereals and legumes. Foods 2019, 8, 362. [CrossRef] [PubMed]

151. Pérez-Corona, M.; Sánchez-Martínez, M.; Valderrama, M.; Rodríguez, M.; Cámara, C.; Madrid, Y. Selenium biotransformation by Saccharomyces cerevisiae and Saccharomyces bayanus during white wine manufacture: Laboratory-scale experiments. Food Chem. 2011, 124, 1050-1055. [CrossRef]

152. Sánchez-Martínez, M.; da Silva, E.G.P.; Pérez-Corona, T.; Cámara, C.; Ferreira, S.L.; Madrid, Y. Selenite biotransformation during brewing. Evaluation by HPLC-ICP-MS. Talanta 2012, 88, 272-276.

153. Singthong, J.; Oonsivilai, R.; Oonmetta-Aree, J.; Ningsanond, S. Bioactive compounds and encapsulation of Yanang (Tiliacora triandra) leaves. Afr. J. Tradit. Complementary Altern. Med. 2014, 11, 76-84. [CrossRef] [PubMed]

154. Quirós-Sauceda, A.E.; Ayala-Zavala, J.F.; Olivas, G.I.; González-Aguilar, G.A. Edible coatings as encapsulating matrices for bioactive compounds: A review. J. Food Sci. Technol. 2014, 51, 1674-1685. [CrossRef] 
155. Djameh, C.; Ellis, W.; Oduro, I.; Saalia, F.; Haslbeck, K.; Komlaga, G. West African sorghum beer fermented with Lactobacillus delbrueckii and Saccharomyces cerevisiae: Fermentation by-products. J. Inst. Brew. 2019, 125, 326-332. [CrossRef]

156. Wang, M.-L.; Choong, Y.-M.; Su, N.-W.; Lee, M.-H. A rapid method for determination of ethanol in alcoholic beverages using capillary gas chromatography. J. Food Drug Anal. 2003, 11, 133-140.

157. Demuyakor, B.; Ohta, Y. Characteristics of single and mixed culture fermentation of pito beer. J. Sci. Food Agric. 1993, 62, 401-408. [CrossRef]

158. Yeboah-Awudzi, M. Microbial Hazard Analysis and Development of Control Measures for Bissap Drink (sobolo). Master's Thesis, Kwame Nkrumah University of Science and Technology, Kumasi, Ghana, 2017.

159. Ayirezang, F.A.; Saba, C.K.S.; Amagloh, F.K.; Gonu, H. Shelf life improvement of sorghum beer (pito) through the addition of moringa oleifera and pasteurization. Afr. J. Biotechnol. 2016, 15, 2627-2636.

160. Avicor, M.; Saalia, F.; Djameh, C.; Sinayobye, E.; Mensah-Brown, H.; Essilfie, G. The fermentation characteristics of single and mixed yeast cultures during pito wort fermentation. Int. Food Res. J. 2015, 22, 102-109.

161. Lyumugabe, F.; Gros, J.; Songa, E.B.; Thonart, P. Sorghum beer brewing using eleusine coracana "Finger Millet" to improve the saccharification. Am. J. Food Technol. 2015, 10, 167-175. [CrossRef]

162. Bamforth, C.W. pH in brewing: An overview. Tech. Q. -Master Brew. Assoc. Am. 2001, 38, 1-9.

163. Attchelouwa, C.K.; Aka-Gbézo, S.; N'guessan, F.K.; Kouakou, C.A.; Djè, M.K. Biochemical and microbiological changes during the Ivorian sorghum beer deterioration at different storage temperatures. Beverages 2017, 3, 43. [CrossRef]

164. Djameh, C.; Ellis, W.; Oduro, I.; Saalia, F.; Blay, Y.; Komlaga, G. West African sorghum beer fermented with Lactobacillus delbrueckii and Saccharomyces cerevisiae: Shelf-life and consumer acceptance. J. Inst. Brew. 2019, 125, 333-341. [CrossRef]

165. Onyenekwe, P.C.; Erhabor, G.O.; Akande, S.A. Characterisation of aroma volatiles of indigenous alcoholic beverages: Burukutu and pito. Nat. Prod. Res. 2016, 30, 558-564. [CrossRef] [PubMed]

166. Lyumugabe, F.; Gros, J.; Thonart, P.; Collin, S. Occurrence of polyfunctional thiols in sorghum beer 'ikigage'made with Vernonia amygdalina 'umubirizi'. Flavour Fragr. J. 2012, 27, 372-377. [CrossRef]

167. Klug, L.; Daum, G. Yeast lipid metabolism at a glance. FEMS Yeast Res. 2014, 14, 369-388. [CrossRef]

168. Saerens, S.M.; Delvaux, F.R.; Verstrepen, K.J.; Thevelein, J.M. Production and biological function of volatile esters in Saccharomyces cerevisiae. Microb. Biotechnol. 2010, 3, 165-177. [CrossRef]

169. Dufour, J.P.; Malcorps, P.; Silcock, P. Control of ester synthesis during brewery fermentation. Brew. Yeast Ferment. Perform. 2003, 213-233.

170. Gülçin, İ.; Huyut, Z.; Elmastaş, M.; Aboul-Enein, H.Y. Radical scavenging and antioxidant activity of tannic acid. Arab. J. Chem. 2010, 3, 43-53. [CrossRef]

171. Shewakena, S.; Chandravanshi, B.; Debebe, A. Levels of total polyphenol, flavonoid, tannin and antioxidant activity of selected Ethiopian fermented traditional beverages. Int. Food Res. J. 2017, 24, 2033-2040.

172. Marova, I.; Parilova, K.; Friedl, Z.; Obruca, S.; Duronova, K. Analysis of phenolic compounds in lager beers of different origin: A contribution to potential determination of the authenticity of Czech beer. Chromatographia 2011, 73, 83-95. [CrossRef]

173. Kao, F.-J.; Chiu, Y.-S.; Chiang, W.-D. Effect of water cooking on antioxidant capacity of carotenoid-rich vegetables in Taiwan. J. Food Drug Anal. 2014, 22, 202-209. [CrossRef]

174. Demuyakor, B. Exploitation of Ghanaian raw materials in tropical beer brewing. Ph.D. Thesis, Hiroshima University, Hiroshima, Japan, 1994.

175. Sanni, A.; Onilude, A.; Fadahunsi, I.; Afolabi, R. Microbial deterioration of traditional alcoholic beverages in Nigeria. Food Res. Int. 1999, 32, 163-167. [CrossRef]

176. Council, N.R. Applications of Biotechnology in Traditional Fermented Foods; National Academies Press: Washington, DC, USA, 1992.

177. Ellis, W.; Oduro, I.; Terkuu, D. Preliminary studies on extension of the shelflife of pito. J. Sci. Technol. (Ghana) 2005, 25, 11-15. [CrossRef]

178. Evera, E.; Abedin Abdallah, S.H.; Shuang, Z.; Sainan, W.; Yu, H. Shelf life and nutritional quality of sorghum beer: Potentials of phytogenic-based extracts. J. Agric. Food. Tech. 2019, 2, 1-14.

179. Cabrera, C.; Lloris, F.; Gimenez, R.; Olalla, M.; Lopez, M.C. Mineral content in legumes and nuts: Contribution to the Spanish dietary intake. Sci. Total Environ. 2003, 308, 1-14. [CrossRef] 
180. Anderson, R.A.; Bryden, N.A.; Polansky, M.M. Dietary chromium intake. Biol. Trace Elem. Res. 1992, 32, 117-121. [CrossRef]

181. Ebong, A.; Chapel, A.; Matinus, N.; Alexander, D. Foliar Fertilization Stuttgar; Fischer-verlag: Frankfurt, Germany, 2006.

182. Dan, E.U.; Ebong, G.A. Impact of cooking utensils on trace metal levels of processed food items. Ann. Food Sci. Technol 2013, 14, 350-355.

183. Dabonne, S.; Koffi, B.; Kouadio, E.; Koffi, A.; Due, E.; Kouame, L. Traditional utensils: Potential sources of poisoning by heavy metals. Br. J. Pharmacol. Toxicol. 2010, 1, 90-92.

184. Oz, S.; Teke, G.; Anli, R.E.; Atakol, O. Heavy Metal Content of Selected Some Turkish Beers. Int. J. Sci. Technol. Res. 2015, 1, 46-56.

185. Debebe, A.; Chandravanshi, B.S.; Abshiro, M. Assessment of essential and non-essential metals in Ethiopian traditional fermented alcoholic beverages. Bull. Chem. Soc. Ethiop. 2017, 31, 17-30. [CrossRef]

(C) 2020 by the authors. Licensee MDPI, Basel, Switzerland. This article is an open access article distributed under the terms and conditions of the Creative Commons Attribution (CC BY) license (http://creativecommons.org/licenses/by/4.0/). 